NBER WORKING PAPER SERIES

CENTRAL BANK TRANSPARENCY:

WHERE, WHY, AND WITH WHAT EFFECTS?

N. Nergiz Dincer

Barry Eichengreen

Working Paper 13003

http://www.nber.org/papers/w13003

\author{
NATIONAL BUREAU OF ECONOMIC RESEARCH \\ 1050 Massachusetts Avenue \\ Cambridge, MA 02138 \\ March 2007
}

State Planning Organization, Ankara, and University of California, Berkeley, respectively. An earlier version was presented to the conference on central banking hosted by the Cournot Center, Paris, 30 November-1 December 2006. We thank Petra Geraats, Pierre Siklos and conference participants for helpful comments. The views expressed herein are those of the author(s) and do not necessarily reflect the views of the National Bureau of Economic Research.

(C) 2007 by N. Nergiz Dincer and Barry Eichengreen. All rights reserved. Short sections of text, not to exceed two paragraphs, may be quoted without explicit permission provided that full credit, including (c) notice, is given to the source. 
Central Bank Transparency: Where, Why, and with What Effects?

N. Nergiz Dincer and Barry Eichengreen

NBER Working Paper No. 13003

March 2007

JEL No. E0,E4,F0

\begin{abstract}
$\underline{\text { ABSTRACT }}$
Greater transparency in central bank operations is the most dramatic change in the conduct of monetary policy in recent years. In this paper we present new information on its extent and effects. We show that the trend is general: a large number of central banks have moved in the direction of greater transparency since the late 1990s. We then analyze the determinants and effects of central bank transparency in an integrated empirical framework. Transparency is greater in countries with more stable and developed political systems and deeper and more developed financial markets. Our preliminary analysis suggests broadly favorable if relatively weak impacts on inflation and output variability.
\end{abstract}

\author{
N. Nergiz Dincer \\ Economic Modeling Department, \\ State Planning Organization \\ Necatibey cad. No:108, rm:1016 \\ Yucetepe, 06100, Ankara \\ Turkey \\ nergiz.dincer@gmail.com \\ Barry Eichengreen \\ Department of Economics \\ University of California \\ 549 Evans Hall 3880 \\ Berkeley, CA 94720-3880 \\ and NBER \\ eichengr@econ.Berkeley.edu
}




\section{Central Bank Transparency: Where, Why, and with What Effects? ${ }^{1}$ Nergiz Dincer and Barry Eichengreen}

\section{Introduction}

Transparency is the most dramatic difference between central banking today and central banking in earlier historical periods. ${ }^{2}$ In recent years a number of central banks have moved in the direction of greater transparency about their objectives, procedures, rationales, models, and data. The question is whether the trend is widespread and whether it is likely to be transitory or enduring. Below we show that this movement in the direction of greater policy transparency is remarkably general. The answer to the question of whether it is likely to prove durable or to be a passing phase is likely to turn on the consequences. Our analysis suggests broadly favorable impacts on inflation and output variability. If institutional arrangements that produce favorable results retain public support, then this suggests that the trend toward greater monetary policy transparency is here to stay.

While there have been a few previous studies along these lines, relatively little is known about actual trends in transparency, their correlates, and their implications. Theory has provided useful insights, as we shall see below, but its implications are less than general. Our goal in this study is therefore to contribute new evidence.

We construct an index of central bank transparency, distinguishing its components and dimensions, for a larger range of countries and years than in previous

\footnotetext{
${ }^{1}$ State Planning Organization, Ankara, and University of California, Berkeley, respectively. An earlier version was presented to the conference on central banking hosted by the Cournot Center, Paris, 30 November-1 December 2006. We thank Petra Geraats, Pierre Siklos and conference participants for helpful comments.

${ }^{2}$ Here we use transparency to mean information disclosure. This minimal definition leaves unspecified whether or not the information set has more than one dimension and if so which dimension is relevant. For more on this, see below.
} 
studies. Both the time dimension and the international dimension shed light on recent trends in transparency. They allow us to ask questions like: in what countries have central banks been growing more transparent, and why? Next we analyze the impact of transparency on inflation persistence, inflation variability and output variability. An advantage of considering both the determinants of transparency and the effects is that we can use our analysis of the determinants to identify instrumental variables that address the concern that an observed correlation between outcomes and transparency reflects the impact of the former on the latter, rather than the other way around.

\section{Reflections on the development of central bank transparency}

Central banks originated as closely held, privately owned suppliers of credit to the government. Because they competed with other financial institutions, they tended to be less than forthcoming about their pricing and portfolio decisions. Because they had a privileged relationship with the state - often with the head of state himself - the treated information as confidential, as properly known only to the bank and its client. That they were less than transparent about their decision making is understandable given these circumstances.

As part of this bargain, central banks gradually acquired their modern competency of regulating supplies of money and credit. Typically they acquired it in the era of commodity money. The obligation of converting their liabilities into specie at a fixed rate of exchange ensured an important element of transparency in their operations. Observers knew something about the institution’s objective function: the central bank assigned a high weight to the maintenance of convertibility. They knew something about 
the model that the central bank used, typically some variant of the price-specie flow model. They were knowledgeable of the instruments used to pursue its objectives, typically the rate at which it discounted other obligations to regulate currency fluctuations, together with ancillary measures to render that discount rate effective. ${ }^{3}$ They observed the success with which the central bank regulated the price of specie. Reflecting the public or semi-public nature of this commitment, central banks published information on changes in gold reserves that were used by market participants to forecast future policies. ${ }^{4}$ In modern studies one aspect of transparency is whether a central bank provides an explicit policy rule or strategy that describes its monetary policy framework; an exchange rate target is one such rule. So it was in this earlier period. The existence of this modicum of transparency was what made it socially acceptable to assign consequential public-policy functions to entities that often had private shareholders, mixed motives, and a good deal of bureaucratic autonomy.

The persistence of currency pegs through much of the $20^{\text {th }}$ century and the tendency to regard as aberrant and exceptional periods when those pegs were in abeyance is one way of understanding why there was not more intense pressure for central banks to reveal more information about their operations. It was easy enough to judge, on the basis of events in foreign exchange markets, whether the central bank was true to its mandate. This perspective suggests that it is no coincidence that the tendency in the last ten years for central banks to become more transparent in other aspects of their operations

\footnotetext{
${ }^{3}$ Meaning that changes had an immediate impact on market conditions.

${ }^{4}$ And, increasingly, on other portfolio aggregates that were deemed relevant to the prospective future maintenance of convertibility.
} 
coincided with a shift toward more flexible exchange rates. ${ }^{5}$ In a growing number of countries, the single thing that had done the most to lend transparency to monetary policy disappeared. The result was pressure to increase other aspects of transparency, if for no other reason than to enhance society’s ability to hold central banks accountable to their ultimate stakeholders.

To be sure, this shift toward greater exchange rate flexibility was not exogenous. It did not occur in isolation from other events in economy and society. As one of us has argued elsewhere, it is best understood in terms of two other late- $20^{\text {th }}$ century trends: financial liberalization and political liberalization. ${ }^{6}$ The deregulation of financial markets and the removal of controls on international financial flows made it impossible for central banks and governments to use one instrument to hit two targets - to peg the exchange rate while at the same time using monetary policy to pursue other goals. Meanwhile, democratization made it more difficult to privilege the exchange rate - to credibly commit to pegging the exchange rate without regard to the implications for other socially relevant economic variables. When unemployment rose to high levels, for example, political pressure for the central bank to do something about it became irresistible. In an environment of deregulated financial markets and capital flows, the exchange rate peg was increasingly a casualty. This was a first channel through which there was impetus to develop further other aspects of central bank transparency.

\footnotetext{
${ }^{5}$ Eichengreen and Razo-Garcia (2006) show that the share of soft pegs in all exchange rate regimes has fallen from about 70 per cent in 1990 to 45 percent in 2004. Soft peggers move to hard pegs (including monetary union in the case of European countries) and floats in a ratio of 3 to 4 . Note that, since the euro floats against other currencies, one would want to group the members of the euro area together with the floating rate countries for purposes of this argument.

${ }^{6}$ See Eichengreen (1996).
} 
There were also other channels linking democratization and financial liberalization to central bank transparency. Democratization directly increased demands for public accountability. Democratic governments are intrinsically more open about their affairs as a way of achieving accountability to their constituents; in this sense central bank transparency (the central bank being an agency of the government) is only a specific instance of the general point. And transparency is one way in which such public accountability can be brought about. It is surely not coincidental that the rise in central bank transparency in Latin America, in Eastern Europe and in Asian countries from Korea to the Philippines coincided with the third wave of democratization.

Democratization also strengthened the argument for central bank independence, a trend that is closely allied to increased transparency. In democratic societies, political pressures are intense (in a sense, this is the very definition of democracy), and there are a variety of arguments for why central banks, when deciding on their tactics, should be sheltered from those pressures via independence. ${ }^{7}$ With the grant of independence come demands for adequate accountability; central banks are asked to provide more information about their operations to enable citizens and their representatives to evaluate the central bank's actions, praise it for its achievements, and take it to task for its failures. In addition, independence may render the central bank more willing to volunteer information about its operations; when a central bank is dependent on the government,

\footnotetext{
${ }^{7}$ The standard approach to this problem focuses on time inconsistency and inflationary bias when the central bank adopts the objective function of the median voter. Independence is then a way of permitting the appointment of central bankers who are more conservative than the median voter as a way of offsetting the inflationary bias that results for inability to precommit. But there are other models that also suggest a link from democratization to central bank independence, such as models of the political business cycle suggesting that a politically-dependent central bank feel pressure to inefficiently loosen in the run-up to elections.
} 
keeping information private is one way that it can advance its own goals relative to those of its political masters. ${ }^{8}$

Finally, financial liberalization made it important that central bank actions should have a stable and predictable impact on market variables. Deregulation eliminated the authorities' ability to control market outcomes directly. The growth of financial markets and transactions made the market response to policies all the more essential for achieving the central bank's ultimate objectives. Volatility, when it occurred, was even more disruptive than before. This made it more important that the central bank communicate with market participants in a way that inspired confidence and avoided causing excessive volatility. Insofar as communication means the regularized transmission of information, the implication was an increase in the extent of central bank transparency. ${ }^{9}$

It is against this backdrop that we ask: what exactly is the state of central bank transparency? And what has been the impact on economic outcomes?

\section{Theory}

Economists are instinctually of the view that more information is better. In the present context they argue that having a central bank more fully communicate its objectives, its assessment of the effects of policy actions, and information about economic conditions will enhance social welfare. Policy being more predictable, agents will be better able to align their decisions with those of the central bank. The economy

\footnotetext{
${ }^{8}$ On these arguments see Geraats (2005) and below.

${ }^{9}$ To what extent this desire to avoid excessive volatility and avoid destabilizing financial markets, while advancing the central bank's other goals, implies the desirability of greater transparency is a disputed issue, as we will see below.
} 
will adjust more smoothly insofar as they can more accurately forecast the time paths of relevant variables.

By the same token, the theory of the second best suggests that removing one distortion may not always lead to a more efficient allocation when other distortions are present. Adding distortions, theorists have thus provided counterexamples where greater transparency may not lead to a welfare improvement.

Transparency has typically been modeled in a Barro-Gordon (1983) setup where there is uncertainty about the central bank's preferences and the central bank may wish to stimulate output to levels above the natural rate. As in Backus and Driffill (1985), the public will use outcomes or actions to infer the central bank's preferences. Because private-sector decisions are taken before disturbances are known, there may be a role for stabilizing policy. But if the central bank prefers a level of output above the natural rate, stabilizing policy may have an inflationary bias. Thus, such models include a number of distortions that make it possible to obtain different results about whether transparency is welfare improving or preferred by the central bank.

Faust and Svensson (2001) consider a model in which the public attempts to infer the central bank's type from information on policy outcomes. Inference is imperfect because of unanticipated monetary control errors that the public observes incompletely. Greater transparency the control error enables agents to infer the central bank's preferences more accurately. In turn this gives the monetary authority an incentive to build a reputation for valuing price stability. The private sector becomes more sensitive to unanticipated policy responses and actions, attenuating the incentive for the central bank to engage in them. The result is thus greater sensitivity of inflation expectations to 
policy actions, less benefit to the central bank of inflating, and less inflationary bias. In this way increased transparency about control errors improves social welfare.

Greater transparency about the central bank’s objectives has similar effects - the central bank is led to moderate its inflationary bias - but in certain cases extreme transparency about objectives may be welfare reducing. Greater transparency about objectives not only eliminates uncertainty about inflation and output but also removes the central bank's incentive to curtail inflation in order to signal its type. Hence neither the central bank nor society may prefer goal transparency.

Making minor modifications of the Faust-Svensson framework, Jensen (2002) shows that increases in transparency about outcomes can be welfare reducing as well. In Faust and Svensson, inflation expectations are formed at the start of the period and current policy decisions affect output only in the future; this means that there are no costs in terms of foregoing stabilization policy. In Jensen’s model, in contrast, not every firm is permitted to change its prices at the beginning of every period, so there are implications for output in the current period. Inflation expectations and hence current inflation become more sensitive to policy when the public is able to infer the central bank’s preferences and hence to predict its future behavior. The central bank is led to pay more attention to inflation. Transparency may be welfare increasing if the central bank lacks credibility and market expectations and reactions provide discipline preventing excessive inflation. But it may be welfare reducing if shocks to output are large and stabilization policy is hamstrung. In general there will be an optimal degree of transparency that trades off these two considerations. 
Geraats (2002a) models the private-sector response to policy actions themselves, not to the outcomes from which policy actions are inferred. The public is imperfectly informed about shocks to the economy and uses the interest rate to infer the central bank’s target. Contrary to Jensen, greater transparency may not hamstring stabilization policy. To the contrary, an opaque central bank may have to limit the variability of its interest rate in order to signal its type. It is forced to smooth the interest rate in order to avoid exciting inflation expectations. Hence it may be less able to counter output shocks.

In addition, when the degree of transparency is endogenous, signaling and selfselection can arise. The public will expect opaque central banks to be more inflationary and it will form higher inflation expectations. Geraats shows that this may be sufficiently costly that even weak central banks prefer transparency, contrary to the implications of other models.

Assuming that inflation expectations are set by the private sector acting strategically instead of by agents passively forming rational expectations further weakens the presumption that more transparency about objectives enhances welfare. Sorensen (1991) considers the case where wages are set by a risk-averse labor union whose demands depend on inflation expectations. Again, uncertainty about the central bank’s objective raises the variance of inflation and output. But since the union is risk averse, it may demand wages lower than those corresponding to its unbiased forecast of inflation in order to limit volatility. This second effect will work to reduce the level of inflation and increase the level of output. ${ }^{10}$ But this effect disappears if the central bank makes its

\footnotetext{
${ }^{10}$ In a similar set-up, Gruner (2002) demonstrates that if the union is sufficiently risk averse, not only the level but also the variance of inflation may turn out to be lower as a consequence of greater uncertainty about the central bank's objectives.
} 
objectives public information, so that the risk aversion of the wage-setting union no longer matters.

Morris and Shin (2002) address a related coordination problem, where individual welfare depends not just on the state of the world but on the actions of other individuals. Starting from a position where both private and public information are imperfect, they show that greater precision of public information can lead individuals to attach inadequate weight to private information. In the absence of coordination motives, the precision attached to the public and private signals will be commensurate with their relative precision. When coordination motives are present, however, agents attach greater weight to the public signal, since they know this to be common information. But since the public signal is noisy, this weight on the public signal may be suboptimal from a social-welfare point of view; agents may be led to coordinate on an inefficient equilibrium. This adverse outcome is more likely the more precise is private information. Svensson (2006) argues that this result obtains only under extreme parameter values when the public signal is very noisy relative to its private counterpart.

This brief survey suffices to make the point. ${ }^{11}$ General conclusions based on theory remain elusive. Results are sensitive to what one assumes about the structure of the economy (the determinants of supply and demand, the channels through which monetary policy affects output and inflation), the stochastic structure (what relationships are subject to disturbances), the information environment (what the central bank knows that the private sector does not and the relative and absolute precision of their signals), the timing of actions and decisions, and the institutional setting (whether the central bank

\footnotetext{
${ }^{11}$ More comprehensive surveys of the theoretical literature include Geraats (2002b) and Carpenter (2004).
} 
has the political independence to take decisions on the basis of an objective function that differs from that of the private sector or the government).

\section{Previous empirics}

Empirical studies of central bank transparency are still in their infancy. Most take the form of detailed studies of individual central banks, describe disclosure practices in detail, and/or attempt to identify an effect of changes in disclosure practices on specific financial and economic variables using time-series data. ${ }^{12}$ They are valuable for demonstrating the feasibility of bringing the concept of transparency to the data. Their limitations are the difficulty of knowing how far to generalize the findings of individual cases and the difficulty of identifying the impact of increased transparency on the basis of a time series, especially when there may be only one significant change in disclosure practices in the sample period and other things were going on at the same time.

More recently, a number of studies have attempted to compare the transparency of different central banks. Typically they measure transparency either for a very limited number of central banks or a single point in time. Examples include Eijffinger and Geraats (2006), who distinguish political transparency (that is, openness about policy objectives), economic transparency (openness about data, models and forecasts), procedural transparency (openness about the way decisions are taken, achieved mainly

\footnotetext{
${ }^{12}$ Examples of studies that attempt to estimate the impact of greater disclosure include Muller and Zelmer (1999) for Canada, Chadha and Noland (2001) for the UK, Haldane and Read (2000) for the UK and US, and Kuttner and Posen (2000) for the US, Germany and Japan. There is a related literature examining the association of having an inflation-targeting regime with various measures of economic performance. This is a good point at which to observe that transparency is generally regarded as integral to the effective implementation of inflation targeting, although countries conventionally characterized as inflation targeters tend to differ in exactly how transparent they are, and inflation targeting as conventionally defined entails more than simply the disclosure of information. Thus, while the concepts overlap, they are distinct. It follows that empirical indices of whether or not a central bank targets inflation and how transparent it is, while correlated, measure different things.
} 
through the release of minutes and votes), policy transparency (openness about the policy implications, achieved through prompt announcement and explanation of decisions), and operational transparency (openness about the implementation of those decisions, in other words about control errors and macroeconomic disturbances affecting their magnitude), and three subcategories within each of these five dimensions. Their overall index is the sum (equally weighted average) of the subindices for these five dimensions. The strength of this approach is its comprehensive, multidimensional definition of transparency; its limitation is that it is constructed for just nine central banks (the Reserve Bank of Australia, Bank of Canada, ECB, Bank of Japan, Reserve Bank of New Zealand, Swedish Riksbank, Swiss National Bank, Bank of England, and Federal Reserve). ${ }^{13}$ The results indicate sharp differences between more and less transparent central banks as of this date (with the Reserve Bank of New Zealand, the Bank of England and the Swedish Riksbank at the top in terms of transparency, and the Reserve Bank of Australia, Bank of Japan and the Swiss National Bank at the bottom).

A related study is Bini-Smaghi and Gros (2001), who like Eijffinger-Geraats consider 15 aspects of central bank transparency. ${ }^{14}$ They implement their index for four countries: the Fed, the Bank of England, the Bank of Japan, and the ECB. De Haan, Amtembrink and Waller (2004) develop a similar index for six countries. ${ }^{15}$ Siklos (2002) expands coverage to 20 central banks, all from advanced industrial countries. There is again considerable overlap with the contemporaneous work of Eiffjinger-Geraats and

\footnotetext{
${ }^{13}$ The index covers the period 1998-2002.

${ }^{14}$ Although they group these into three broad categories rather than five.

${ }^{15}$ In an unpublished companion paper (De Haan and Amtembrink 2002) two of the authors apply a similar methodology to 15 countries.
} 
Bini-Smaghi-Gros. ${ }^{16}$ Siklos’ ranking has the Bank of England, the Fed and the Riksbank as one, two and three, and the Austrian National Bank, the Bank of France and the National Bank of Belgium bringing up the rear.

The most comprehensive such study is Fry et al. (2000). The strength of their analysis is its wide country coverage, based on a survey of 94 central banks. Its limitation is a more restrictive definition of transparency. Their measure is an equallyweighted average of three elements: whether the central bank provides prompt public explanations of its policy decisions, the frequency and form of forward-looking analysis provided to the public, and the frequency of bulletins, speeches and research papers. One can question the unbiasedness of an index constructed on the basis of a survey of central banks, especially when that survey is administered by a multilateral with a known interest in transparency. And that their data are for 1998 is less than ideal, given the changes in transparency practices in subsequent years.

A number of authors have examined the relationship of these measures to economic and financial variables. Demertzis and Hughes Hallett (2003) employ the Eijffinger-Geraats index for 2001 to examine the relationship between central bank transparency and the level and variability of inflation and the output gap in the period 1990-2001. The results suggest a negative relationship between inflation variability and central bank transparency, but not between the level of inflation and transparency. The former relationship appears to be driven by the subindices for economic and operational transparency (whether the central bank discloses information about data, its models, its

\footnotetext{
${ }^{16}$ Siklos takes an unweighted average of 11 subindices, whereas Eiffjinger and Geraats take an unweighted average of five. But Eiffjinger and Geraats distinguish three equally-weighted aspects of each of their five dimensions, making for a total of 15 questions. Siklos distinguishes subtopics in the case of three of his 11 questions.
} 
forecasts, and the disturbances to which monetary policy is subject). There is no evident relationship between transparency and average output deviations but a strong positive relationship between transparency and the variability of output. The latter seems to be driven by the subindex for operational transparency. The positive association of transparency with output variability is consistent with theoretical studies suggesting that more transparency may make for more volatile inflation expectations, to which a central bank may respond by using its monetary instruments less actively, limiting its effectiveness as an instrument of stabilization policy. ${ }^{17}$ However, the fact that the transparency data are for the end of the period over which economic performance is analyzed suggests that what these correlations may be picking up are the economic determinants of transparency rather than its consequences. ${ }^{18}$

Chortareas et al. (2001) and Cecchetti and Krause (2001) utilize the Fry et al. index. Chortareas et al. focus on whether the central bank publishes a forward-looking analysis of economic prospects: they find that this aspect of disclosure reduces average inflation, even in the presence of controls. ${ }^{19}$ Cecchetti and Krause examine the impact of transparency on inflation and output variability and find a weak negative association with a weighted average of the two variability measures.

In sum, existing empirical studies do not all reach consistent conclusions. Many are based on very limited country samples or utilize evidence for a single point in time. Cross sections, unlike panels, do not permit the inclusion of country fixed effects, giving

\footnotetext{
${ }^{17}$ That said, it is clear that one should not put too much weight on empirical results when there are only nine observations and nothing is done to control for other country characteristics and the possibility of reverse causality.

${ }^{18}$ In Eijffinger and Geraats (2004) the authors show that there is no relationship between their index for nine central banks and subsequent economic performance.

${ }^{19}$ Not surprisingly, it does not hold for countries with pegged exchange rates, for which inflation is given by foreign conditions.
} 
grounds for worrying that an observed correlation between transparency and economic outcomes may be picking up the effects of other country characteristics that are difficult to capture. Moreover, central banks that are transparent about their policies are not likely to be selected randomly from the larger population. The theoretical literature suggests that there are systematic reasons, having to do with a country’s history, its economic structure, and even the behavior of the economic and financial variables of interest, why its central bank may prefer more or less transparency. A convincing empirical analysis will have to take these considerations into account.

\section{Data}

Our indices of central bank transparency replicate and extend those of Eijffinger and Geraats. Their approach has the advantage of acknowledging that the phenomenon has multiple dimensions. ${ }^{20}$ The result is 15 subindices, described in detail in the appendix, designed to capture five broad aspects of transparency: political, economic, procedural, policy and operational. The overall index thus runs from 0 to 15 . Adopting the same criteria used by these previous investigators facilitates comparison across studies and frees us of suspicions that we have constructed our measures so as to maximize or minimize the impact of transparency.

We draw our data from information on central banks’ websites and in their statutes, annual reports, and other published documents, rather than sending a survey instrument to the central banks themselves and relying on the subjectivity of responding staff. But we follow Fry et al. by gathering this information for as large a number of central banks as possible. In addition we gather the same information for every year from

\footnotetext{
${ }^{20}$ Rather than focusing on a small handful of dimensions, as in Fry et al.
} 
1998 through 2005. Where there was a change in some aspect of transparency over the course of a calendar year, we took the value that prevailed for the largest share of the year. ${ }^{21}$

We were able to assemble this information for 100 central banks. This is the majority of central banks in the world. ${ }^{22}$ Most of the omissions are central banks of micro-states: our sample includes the central banks of all large, systemically significant countries. $^{23}$

Table 1 shows the results by country and region. The most transparent central banks in 2005, according to our coding, were, in descending order, the Reserve Bank of New Zealand, the Swedish Riksbank, the Bank of England, the Czech National Bank, the Bank of Canada, the ECB, and the Central Bank of the Philippines. We see here a number of countries that have received high marks for transparency in previous studies (New Zealand, Sweden, the UK, Canada) but also others (the Czech Republic, the Philippines), which is a reminder of the advantages of broad country coverage and of the fact that a number of countries with relatively opaque central banking practices have been moving in the direction of greater transparency. The seven least transparent central banks were those of Aruba, Bermuda, Ethiopia, Kuwait, Libya, Saudi Arabia and Yemen.

\footnotetext{
${ }^{21}$ Starting in 1998 facilitates comparisons of our measure with that of Fry et al. Adding this time dimension was particularly challenging, since many central bank websites describe current practice but not that of prior years. For this we had to rely mainly on published documents. We were able to access a relatively complete run of these on the basis of holdings in the University of California and Joint IMFWorld Bank libraries. We are grateful to the staff of the Joint Bank-Fund library for granting us access to their collection.

${ }^{22}$ Recall that there are more countries than there are central banks, given the existence of monetary unions.

${ }^{23}$ But there are a few additional omissions, reflecting cases where we were not able to glean information from a central bank's website or its publications. And in cases where the central bank provides this information only in the language of its own country and we could not translate it. Among the omissions from our sample are Bolivia, Ecuador, Chad, Iran, and Afghanistan. We are aware that this creates a form of sampling bias: we tend to oversample more transparent central banks. There exist econometric corrections for this bias (involving strong assumptions), although we have not implemented these yet. Our defense is that the number of consequential omissions is relatively slight.
} 
Table 2 shows our coding of the 15 individual components for these 14 countries as of 2005.

More generally, we can compare different dimensions of central bank transparency. In 2005, 63 central banks received scores of 2 or more for political transparency (inter alia, providing a quantitative definition of their objectives to the public). ${ }^{24}$ Economic transparency (disclosing data, the policy model and forecasts) is less; only 5 central banks receive the highest possible rating. The picture is similar for procedural transparency (the release of minutes and votes), where only three central banks receive the highest possible score. ${ }^{25}$ And again for policy transparency (prompt announcement and comprehensive explanation of policy decisions), where only the Reserve Bank of New Zealand, the Swedish Riksbank and the Fed receive a score of 2.5. No central bank receives a perfect score of 3 for operational transparency (release of information about disturbances, control errors, etc.)

Taking unweighted averages of the countries making up a region (as in Table 1), we see the highest level of transparency in Australia-New Zealand, followed by Western Europe, Northern Europe, South East Asia, Southern Africa, and North America. That South East Asia and Southern Africa are scored as more transparent than North America is a figment of the unweighted averages. When we instead take GDP-weighted averages, as in Table 3, the most transparent regions as of 2005, in descending order, are Europe (led by Northern Europe), Oceania, Southern Africa (dominated by South Africa) and North America; lower weights on its relatively transparent small economies cause South East Asia to drop down. Either way, the lowest levels of transparency, starting from the

\footnotetext{
${ }^{24}$ Up from 47 in 1998.

${ }^{25}$ Up from 2 in 1998, where the addition is Sweden.
} 
bottom, are those of Northern Africa, Eastern Africa, Western Africa, and Melanesia - no surprises there.

We can compare our index (denoted DE) for 1998 with that of Fry et al. for the same year for the 67 countries that are common to the two samples. The two measures have a correlation coefficient of 0.57 . For ease of comparison, in Figure 1 both indices are scaled to run from zero to $100 .{ }^{26}$ The case where our estimate of transparency exceeds that of Fry et al. by the most is Uruguay, while that for which the opposite is true is Indonesia. ${ }^{27}$ We do not have a ready explanation for the coding differences for these particular observations.

Turning to trends over time, the average transparency score in our sample rises from 3.4 in 1998 and 5.2 in 2005. Strikingly, none of our 100 countries moved in the direction of less transparency over this period. Figure 2 compares our measure of transparency in 1998 and 2005 (with 2005 on the vertical axis). There are only 11 countries on the diagonal, indicating no increase in transparency, while the remaining 89 cases are all above and to its left.

Figure 3 shows transparency by level of economic development (again, using weighted averages). Consistent with the preceding discussion, central banks in the advanced countries are more transparent than central banks in emerging markets (defined as middle-income countries with significant links to international financial markets), which in turn are more transparent than central banks in developing countries. Consistent with Figure 2 above, there have been increases in central bank transparency in all three

\footnotetext{
${ }^{26}$ It is not surprising that central bank staff, when asked their subjective opinion of the transparency of their own institution, rank it higher than we rate it on the basis of published information.

${ }^{27}$ The other two cases where our measure of transparency is most dramatically above that of Fry et al. are Mauritius and Bahrain.
} 
country groups. Perhaps most strikingly, the increase among emerging markets is, on average, as large in absolute value as the increase among advanced countries; the corresponding increase among developing countries is smaller. Much of the increase in emerging markets is centered in the period following the Asian crisis and again in the early parts of the current decade.

\section{Determinants}

We now use regression analysis to further characterize differences in central bank transparency. Our goals here are to work toward an explanation for these variations and also to identify instruments for our analysis of the consequences of transparency.

We start with the 1998-2004 cross section, with all variables averaged over the period. ${ }^{28}$ We regress transparency on a vector of economic determinants: per capita income, inflation history (defined as the lagged log first difference of the consumer price index), the de facto exchange rate regime (the Reinhart-Rogoff 2003 version as updated by Eichengreen and Razo-Garcia 2006), and financial depth (defined as the ratio of M2 to GDP). In addition we include a range of potential political determinants: rule of law, political stability, voice and accountability, and government efficiency (all taken from Kaufmann, Kraay and Mastruzzi, 2005). Since the political variables are highly correlated, we include them one at a time.

The results (Table 4) suggest, not surprisingly, that per capita GDP, which proxies for the general level of economic and institutional development, is the most robust

\footnotetext{
${ }^{28} 2004$ being the most recent year for which all the ancillary variables are available. The results for individual years show the same patterns but lower levels of significance. This makes sense, insofar as changes in central-bank practice develop gradually and are unlikely to respond to changes in economic or political conditions in a single year; looking at longer-period averages thus increases the signal-to-noise ratio.
} 
correlate of overall transparency. This could have been predicted from Figure 3. In addition, countries with more flexible exchange rates (where a larger value of the index denotes greater flexibility) tend to be more transparent in the conduct of monetary policy, as anticipated in Section 2 - the absence of an exchange rate peg eliminating one traditional device for monitoring central bank actions. ${ }^{29}$ A number of the political variables are significant, although at levels that vary with the proxy used. ${ }^{30}$ Greater transparency characterizes central bank operations in countries that rank higher in terms of rule of law, that have more stable political systems, that have higher ratings in terms of voice and accountability, and that are more favorably regarded in terms of government efficiency. ${ }^{31}$ The correlation of these political variables with central bank transparency will be useful when we consider the impact of transparency on economic and financial variables below. $^{32}$ As a form of sensitivity analysis Table 5 adds openness and interacts it with the exchange rate regime: the results suggest that greater openness is associated with greater transparency if a country has a relatively flexible exchange rate but with less

\footnotetext{
${ }^{29}$ Readers may be concerned that the exchange rate regime is endogenous - that countries with experience with monetary policy transparency may be better able to operate regimes of grater flexibility. Fortunately, dropping the exchange-rate regime variable left the other results unchanged.

${ }^{30}$ The other variables do not approach statistical significance at conventional confidence levels. For what they are worth, the point estimates suggest that central banks of countries with a history of inflation tend to be more transparent, presumably as part of a credibility-building strategy. This is not something that would have been anticipated from the contrast between transparency in advanced and developing countries.

Central banks in more open economies appear to be less transparent; again, this is not something that we would have anticipated from high-profile cases like New Zealand or Sweden. We will have more to say about these correlations below.

${ }^{31}$ When we include multiple political variables (as we do in additional regressions available on request), significance levels vary, but it is voice and accountability and government efficiency that are most often significant at standard confidence levels.

${ }^{32}$ That is, while it is not hard to come up with an argument for why the transparency of monetary policy should affect inflation, financial markets, or the development of trade, it is harder to concoct a story for why it should have a first-order effect on, say, rule of law, which depends on the larger political and social setting and is the product of a country's history. It can thus be argued that such political variables satisfy the two criteria for a valid instrument: exogeneity and correlation with the explanatory variable of interest.
} 
transparency if the country has a relatively rigid currency; again this accords with intuition and casual observation.

We can also use this specification to consider factors influencing trends in transparency. In Tables 6 and 7 we pool the annual observations and estimate fixedeffects models (including separate intercepts for each country). ${ }^{33}$ The estimates are now driven by the time series variation in the data; they thus tell us something about why central bank practice is evolving in the direction of greater transparency. The exchange rate regime and per capita income continue to enter as before. However, greater political and social stability now appears to have a negative impact on monetary-policy transparency. ${ }^{34}$ The result is not intuitive because, as Figure 4 shows, there is a positive cross-section correlation between the two variables. Recall, however, that fixed-effects regressions eliminate the cross section variation. We suspect that what we are seeing is that advanced countries with highly-transparent central banks and stable political systems cannot move much further in those directions (they contribute relatively little to the variation in the data), while countries that are not as admirable in terms of political stability and rule of law (Brazil, Colombia, Thailand, Philippines) have been moving in the direction of greater central bank transparency precisely in order to insulate monetary policy from political problems. ${ }^{35}$

\footnotetext{
${ }^{33}$ The standard Hausman and Breusch-Pagan tests reject random effects and simple pooling in favor of fixed effects (the Hausman test statistic is reported at the foot of the tables). See also the further discussion below.

${ }^{34}$ We find the same thing when we include different political variables, individually or in combination.

${ }^{35}$ We can also analyze the determinants of the components of the transparency index to gain further insight into exactly how practice responds to these economic and political factors. Not surprisingly, political transparency is a positive function of political development and stability (whether this is measured by rule of law, political turnover, voice and accountability or government efficiency). The cross-section regressions for 2004 also suggest, more surprisingly, that political transparency appears to decline with financial depth. However, regressions for other years and for the period averages indicate that this result is not robust. Economic transparency (the public disclosure of data, the policy model and forecasts) is again
} 
Overall, the analysis confirms that transparency is greater in countries with more stable and developed political systems and deeper and more developed financial markets. The one surprise is the negative association between some components of transparency and economic openness, although the robustness of this association may be questioned.

\section{Effects}

We now explore the effects of monetary policy transparency. Some previous studies (viz. Mishkin, 2004) suggest that greater transparency should be associated with a reduction in uncertainty about future policy actions and thus with a reduction in inflation volatility. Others (viz. Ball and Sheridan, 2005) have found evidence of a reduction in the average rate of inflation but not in the level or volatility of growth. Here we consider the impact on output variability, inflation variability, and inflation persistence. In contrast to previous studies we acknowledge the endogeneity of monetary policy transparency by using the political variables utilized to explain the degree of transparency in Section 5 as instruments for transparency in this section's (second-stage) regressions. Specifically, in the results reported below we use rule of law as an instrument for central bank transparency. ${ }^{36}$

positively related to political development and stability. It is positively related to financial development, as one would expect. More surprisingly, it appears to be less in more open economies, other things equal. Procedural transparency (the release of minutes and votes) is related, again positively, only to political development and stability. In contrast, policy transparency (prompt announcement and comprehensive explanation of policy decisions) is greater in countries with more stable and open political systems but also less in more open economies, or so the regressions on the period averages suggest. Finally, it would appear that operational transparency (release of information about disturbances, control errors, etc.) is again greater in countries with more stable political systems but also in countries with more developed financial markets, while it is less in more open economies. These results are available from the authors on request.

${ }^{36}$ Results using alternative instrument lists are discussed below and are available from the authors on request. 
Table 8 reports the estimates for inflation variability. Note that in each column we report the sum of squared residuals comparing the change in the point estimates with the loss of efficiency when instrumental variables are used; the change in the point estimates being relatively large, this supports our use of instrumental variables.

The regressions suggest that past inflation is positively related to inflation variability, while financial depth is negatively related to inflation variability. Of particular interest is the coefficient on transparency, which is negative and, in most cases, statistically significant. This is consistent with theories suggesting that greater monetarypolicy transparency allows the public to react more quickly to policy adjustments, in turn discouraging the authorities from attempting to manipulate inflation in the pursuit of other objectives.

Table 9 considers inflation persistence. Transparency enters negatively, consistent with the notion that greater policy transparency allows the public to adjust more quickly, in turn limiting the incentive for the central bank to run persistently inflationary policies in an effort to achieve objectives other than price stability. However, the coefficient in question is statistically significant at the 90 per cent level in only two of six specifications. Table 10 considers an alternative formulation where the dependent variable is current inflation and the explanatory variables include lagged inflation (the coefficient on which picks up inflation persistence) and also the interaction of lagged inflation with the fitted value of transparency (from the first-stage regression). The coefficient on the interaction term, which tells us whether inflation persistence is greater, lesser or no different in countries where monetary policy is more transparent, is 
negative, consistent with earlier results, and it is also significantly different from zero at the 90 per cent level in all three columns.

Finally, in Table 11 we consider the determinants of output variability. Here analytical work offers competing predictions: as noted above, some models suggest that greater policy transparency should be associated with more stability because it allows the public to adjust more quickly to policy actions; but others suggest that a more transparent monetary policy may be associated with more output volatility because it prevents the authorities from using policy as actively to offset output fluctuations (policy actions instead feeding through more quickly into inflation and hence deterring policy activism) or because coordination externalities cause individuals to attach excessive weight to the public signal. A limitation of these results is that we have only annual data on output for the broad sample of countries that is our subject, forcing us to measure output variable as the standard deviation of the growth rate over the most recent three year period. ${ }^{37}$ Be that as it may, the results are consistent with a negative impact of monetary policy transparency on output variability. ${ }^{38}$

\section{Conclusion}

Greater transparency in central bank operations is the most dramatic recent change in the conduct of monetary policy. We understand it as a response to other

\footnotetext{
${ }^{37}$ The current calendar year and its two immediate predecessors.

${ }^{38}$ We also conducted a number of robustness checks. For example, we reestimated the equations using fixed effects; doing so, and relying exclusively on the time series variation in the data, produces weaker evidence of real effects of transparency. Rather than taking an unweighted average of our 15 dimensions of transparency, we constructed their first principal component and used its instrumented value as the transparency-related explanatory variable in Tables 8-11. Again the results are somewhat weaker than before. As noted above, we alternatively used different political variables, or combinations of political variables, as instruments for transparency in Tables 8-11. Doing so did not weaken the results for output variability in Table 11, although some alternative combinations of instruments produced lower levels of significance in Tables 8-10.
} 
changes in the monetary policy environment. It is a way of ensuring the accountability of policy makers when the traditional mechanisms for doing so - public monitoring of compliance with an exchange rate commitment and direct oversight by a government with formal control - are in decline, reflecting the shift to flexible exchange rates and central bank independence.

In this paper we have presented new information on the extent of the trend and its effects. The trend is general - a large number of central banks have moved in the direction of greater transparency in recent years. The question is whether it will prove durable or be a passing phase. In part, the answer depends on the consequences. Our preliminary analysis suggests broadly favorable if relatively weak impacts on inflation and output variability. If institutional arrangements that produce favorable results retain public support, then this suggests that the trend toward greater monetary policy transparency is here to stay.

The other way of approaching this question is to ask whether the changes in the larger policy environment that precipitated the move toward greater transparency in monetary policy might themselves be rolled back. We see the abandonment of pegged exchange rates as a response to financial liberalization, and greater central bank independence as a way of insulating the conduct of monetary policy from short-term political pressures in democracies. If financial globalization and political democratization are here to stay, then so too is greater transparency in the conduct of monetary policy. 


\section{Data Appendix}

This appendix describes the construction of the transparency index. The index is the sum of the scores for answers to the fifteen questions below ( $\min =0$, $\max =15$ ).

\section{Political Transparency}

Political transparency refers to openness about policy objectives. This comprises a formal statement of objectives, including an explicit prioritization in case of multiple goals, a quantification of the primary objective(s), and explicit institutional arrangements. (a) Is there a formal statement of the objective(s) of monetary policy, with an explicit prioritization in case of multiple objectives?

No formal objective(s) $=0$.

Multiple objectives without prioritization $=1 / 2$.

One primary objective, or multiple objectives with explicit priority $=1$.

(b) Is there a quantification of the primary objective(s)?

$$
\begin{aligned}
& \text { No }=0 . \\
& \text { Yes }=1 .
\end{aligned}
$$

(c) Are there explicit contacts or other similar institutional arrangements between the monetary authorities and the government?

No central bank contracts or other institutional arrangements $=0$.

Central bank without explicit instrument independence or contract $=1 / 2$.

Central bank with explicit instrument independence or central bank contract although possibly subject to an explicit override procedure $=1$.

\section{Economic Transparency}

Economic transparency focuses on the economic information that is used for monetary policy. This includes economic data, the model of the economy that the central bank employs to construct forecasts or evaluate the impact of its decisions, and the internal forecasts (model based or judgmental) that the central bank relies on.

(a) Is the basic economic data relevant for the conduct of monetary policy publicly available? (The focus is on the following five variables: money supply, inflation, GDP, unemployment rate and capacity utilization.)

Quarterly time series for at most two out of the five variables $=0$.

Quarterly time series for three or four out of the five variables $=1 / 2$.

Quarterly time series for all five variables $=1$.

(b) Does the central bank disclose the macroeconomic model(s) it uses for policy analysis?

$$
\text { No }=0 \text {. }
$$$$
\text { Yes }=1 \text {. }
$$

(c) Does the central bank regularly publish its own macroeconomic forecasts?

No numerical central bank forecasts for inflation and output $=0$.

Numerical central bank forecasts for inflation and/or output published at less than quarterly frequency $=1 / 2$.

Quarterly numerical central bank forecasts for inflation and output for the medium term (one to two years ahead), specifying the assumptions about the policy instrument (conditional or unconditional forecasts) $=1$. 


\section{Procedural Transparency}

Procedural transparency is about the way monetary policy decisions are taken.

(a) Does the central bank provide an explicit policy rule or strategy that describes its monetary policy framework?

$$
\begin{aligned}
& \text { No }=0 . \\
& \text { Yes }=1 .
\end{aligned}
$$

(b) Does the central bank give a comprehensive account of policy deliberations (or explanations in case of a single central banker) within a reasonable amount of time?

No or only after a substantial lag (more than eight weeks) $=0$.

Yes, comprehensive minutes (although not necessarily verbatim or attributed) or explanations (in case of a single central banker), including a discussion of backward and forward-looking arguments $=1$.

(c) Does the central bank disclose how each decision on the level of its main operating instrument or target was reached?

No voting records, or only after substantial lag (more than eight weeks) $=0$.

Non-attributed voting records $=1 / 2$.

Individual voting records, or decision by single central banker $=1$.

\section{Policy Transparency}

Policy transparency means prompt disclosure of policy decisions, together with an explanation of the decision, and an explicit policy inclination or indication of likely future policy actions.

(a) Are decisions about adjustments to the main operating instrument or target announced promptly?

No or only after the day of implementation $=0$.

Yes, on the day of implementation $=1$.

(b) Does the central bank provide an explanation when it announces policy decisions?

No $=0$.

Yes, when policy decisions change, or only superficially $=1 / 2$.

Yes, always and including forwarding-looking assessments $=1$.

(c) Does the central bank disclose an explicit policy inclination after every policy meeting or an explicit indication of likely future policy actions (at least quarterly)?

$$
\text { No }=0 \text {. }
$$$$
\text { Yes }=1 \text {. }
$$

\section{Operational Transparency}

Operational transparency concerns the implementation of the central bank's policy actions. It involves a discussion of control errors in achieving operating targets and (unanticipated) macroeconomic disturbances that affect the transmission of monetary policy. Furthermore, the evaluation of the macroeconomic outcomes of monetary policy in light of its objectives is included here as well.

(a) Does the central bank regularly evaluate to what extent its main policy operating targets (if any) have been achieved?

No or not very often (at less than annual frequency) $=0$. 
Yes but without providing explanations for significant deviations $=1 / 2$.

Yes, accounting for significant deviations from target (if any); or, (nearly) perfect control over main operating instrument/target $=1$.

(b) Does the central bank regularly provide information on (unanticipated)

macroeconomic disturbances that affect the policy transmission process?

No or not very often $=0$.

Yes but only through short-term forecasts or analysis of current macroeconomic developments (at least quarterly) $=1 / 2$.

Yes including a discussion of past forecast errors (at least annually) $=1$.

(c) Does the central bank regularly provide an evaluation of the policy outcome in light of its macroeconomic objectives?

No or not very often (at less than annual frequency) $=0$.

Yes but superficially $=1 / 2$.

Yes, with an explicit account of the contribution of monetary policy in meeting the objectives $=1$. 


\section{References}

Ball, Lawrence and Niamh Sheridan (2005), “Does Inflation Targeting Matter?” in Ben Bernanke and Michael Woodford (eds), The Inflation-Targeting Debate, Chicago: University of Chicago Press, pp.249-278.

Barro, Robert and Roger Gordon (1983), “A Positive Theory of Monetary Policy in a Natural Rate Model,” Journal of Political Economy 91, pp. 589-610.

Bini-Smaghi, Lorenzo and Daniel Gros (2001), "Is the ECB Sufficiently Accountable and Transparent?” European Network of Economic Policy Research Institutes Working Paper no. 7 (September).

Carpenter, Seth (2004), unpublished manuscript, Board of Governors of the Federal Reserve System.

Cecchetti, Steven and Stefan Krause (2001), “Central Bank Structure, Policy Efficiency and Macroeconomic Performance: Exploring the Empirical Relationships,” NBER Working Paper no. 8354 (July).

Chadha, Jagjit and Charles Nolan (2001), "Inflation Targeting, Transparency and Interest Rate Volatility: Ditching 'Monetary Mystique’ in the UK,” Journal of Macroeconomics 23, pp. 349-366.

Chortareas, Georgios, David Stasavage and Gabriel Sterne (2001), "Does It Pay to be Transparent? International Evidence from Central Bank Forecasts,” Bank of England Working Paper no. 143.

De Haan, Jakob and Fabian Amtenbrink (2002), “A Non-Transparent European Central Bank: Who is to Blame?” Paper presented to the conference on Monetary Policy Transparency, London: Bank of England (May).

De Haan, Jakob, Fabian Amtenbrink and Sandra Waller (2004), “The Transparency and Credibility of the European Central Bank,” Journal of Common Market Studies 42, pp. 775-794.

Demertzis, Maria and Andrew Hughes Hallett (2003), “Central Bank Transparency in Theory and Practice,” unpublished manuscript, Netherlands Bank and Vanderbilt University (January).

Eichengreen, Barry (1996), Globalizing Capital: A History of the International Monetary System, Princeton: Princeton University Press. 
Eichengreen, Barry and Raul Razo-Garcia (2006), "The International Monetary System in the Last and Next Twenty Years,” Economic Policy 47, pp. 393-442.

Eijffinger, Sylvester and Petra Geraats (2004), "How Transparent are Central Banks?” Cambridge Working Paper in Economics 0411 (January).

Eijffinger, Sylvester and Petra Geraats (2006), "How Transparent are Central Banks?” European Journal of Political Economy 22, pp.1-22.

Eijffinger, Sylvester, Marco Hoeberichts and Eric Schaling (2000), “A Theory of Central Bank Accountability,” CEPR Discussion Paper no. 2354 (January).

Faust, Jon and Lars Svensson (2001), “Transparency and Credibility: Monetary Policy with Unobservable Goals,” International Economic Review 42, pp. 369-397.

Fry, M, D. Julius, L. Mahadeva , S. Roger and G. Sterne (2000), "Key Issues in the Choice of a Monetary Policy Framework,” in L. Mahadeva and G. Sterne (eds), Monetary Policy Frameworks in a Global Context, London: Routledge, pp. 1-216.

Geraats, Petra M. (2002a), "Why Adopt Transparency? The Publication of Central Bank Forecasts,” unpublished manuscript, University of Cambridge (July).

Geraats, Petra M. (2002b), “Central Bank Transparency,” Economic Journal 112, pp. F532-565.

Geraats, Petra M. (2005), “Political Pressures and Monetary Mystique,” Cambridge Working Papers in Economics no. 0557 (December).

Geraats, Petra M. (2006), “Transparency of Monetary Policy: Theory and Practice,” CESifo Economic Studies 52, pp.111-152.

Gersbach, H. (1998), “Financial Intermediation with Market Side Switching,” unpublished manuscript, University of Heidelberg.

Gruner, H. P. (2002), "How Much Should Central Banks Talk? - A New Argument,” Economics Letters 77, pp. 195-198.

Haldane, Andrew and Vicky Read (2000), "Monetary Policy Surprises and the Yield Curve,” Bank of England Working Paper no. 106.

Jensen, Henrik (2002), “Optimal Degrees of Transparency in Monetary Policymaking,” Scandinavian Journal of Economics 104, pp.399-424.

Kaufmann, Daniel, Aart Kraay, and Massimo Mastruzzi (2005), “Governance Matters IV: Governance Indicators for 1996-2004,” unpublished manuscript, the World Bank (May). 
Kuttner, Kenneth and Adam Posen (2000), “Inflation, Monetary Transparency, and G3 Exchange Rate Volatility,” Working Paper 00-6, Washington, D.C.: Institute for International Economics (July).

Mishkin, Frederic (2004), "Why the Fed Should Adopt Inflation Targeting," International Finance 7, pp.117-127.

Morris, Steven and Hyun Shin (2002), “The Social Value of Public Information,” American Economic Review 92, pp.1521-1534.

Muller, Philippe and Murray Zelmer (1999), “Greater Transparency in Monetary Policy: Impact on Financial Markets,” Bank of Canada Technical Report 86, Ottawa: Bank of Canada (August).

Reinhart, Carmen, Kenneth Rogoff and Miguel Savastano (2003), “Debt Intolerance,” Brookings Papers on Economic Activity 1, pp.1-74.

Shaling, Eric and Charles Nolan (1998), "Monetary Policy Uncertainty and Inflation: The Role of Central Bank Accountability,” De Economist 146, pp. 585-602.

Siklos, Pierre (2002), The Changing Face of Central Banking: Evolutionary Trends Since World War II, New York: Cambridge University Press.

Sørensen JR. (1991) "Political Uncertainty and Macroeconomic Performance", Economics Letters 37, 4377-381

Svensson, Lars (2006), “The Social Value of Public Information: Morris and Shin (2002) is Actually Pro-Transparency, not Con,” American Economic Review 96, pp.448-452.

Walsh, C. E. (1999), “Announcements, Inflation Targeting and Central Bank Incentives”, Economica 66 (262), pp. 255-69. 
Figure 1. Comparison of DE and Fry et al. Indices for 1998

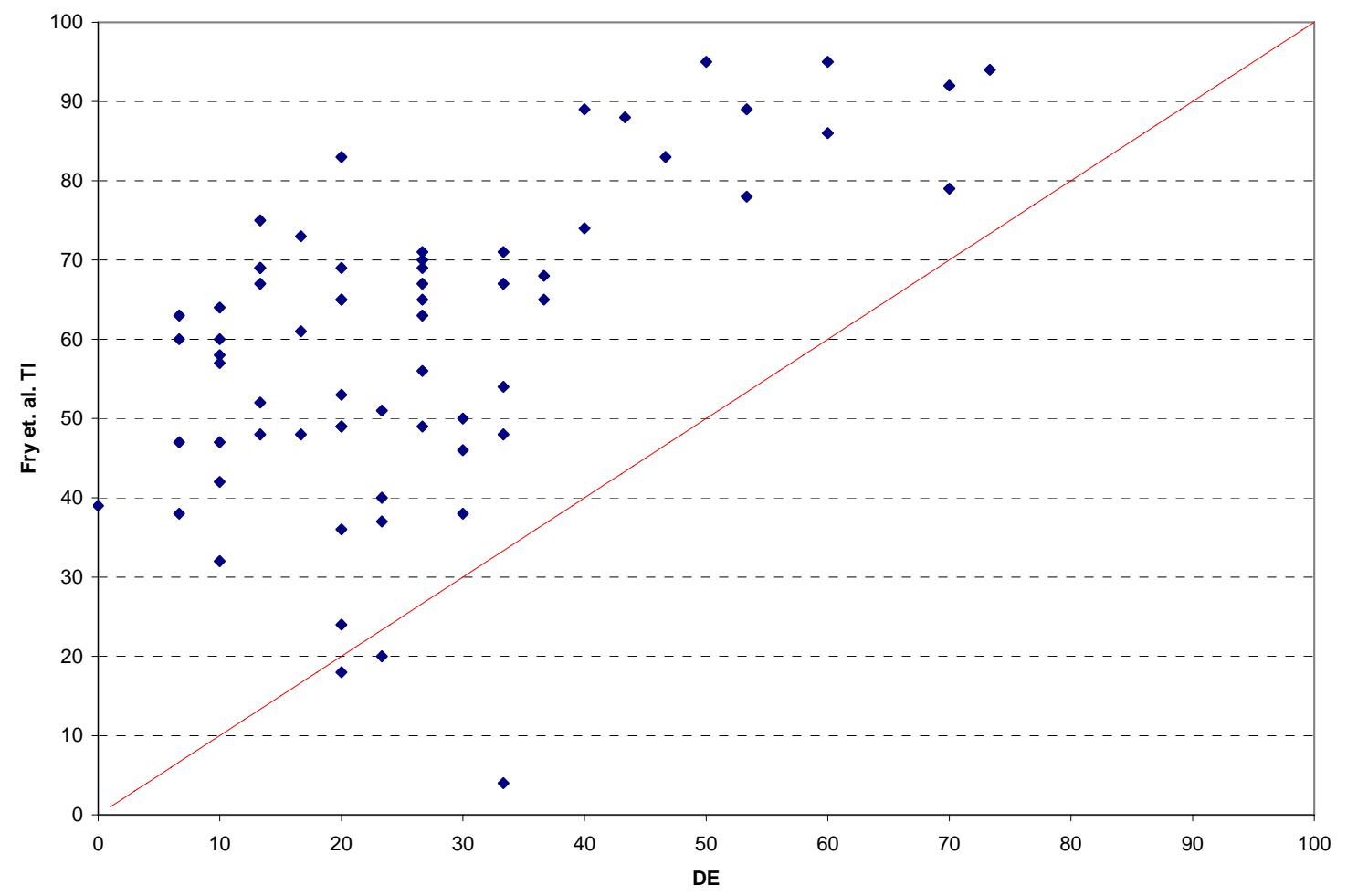


Figure 2. Comparison of Transparency in 1998 and 2005

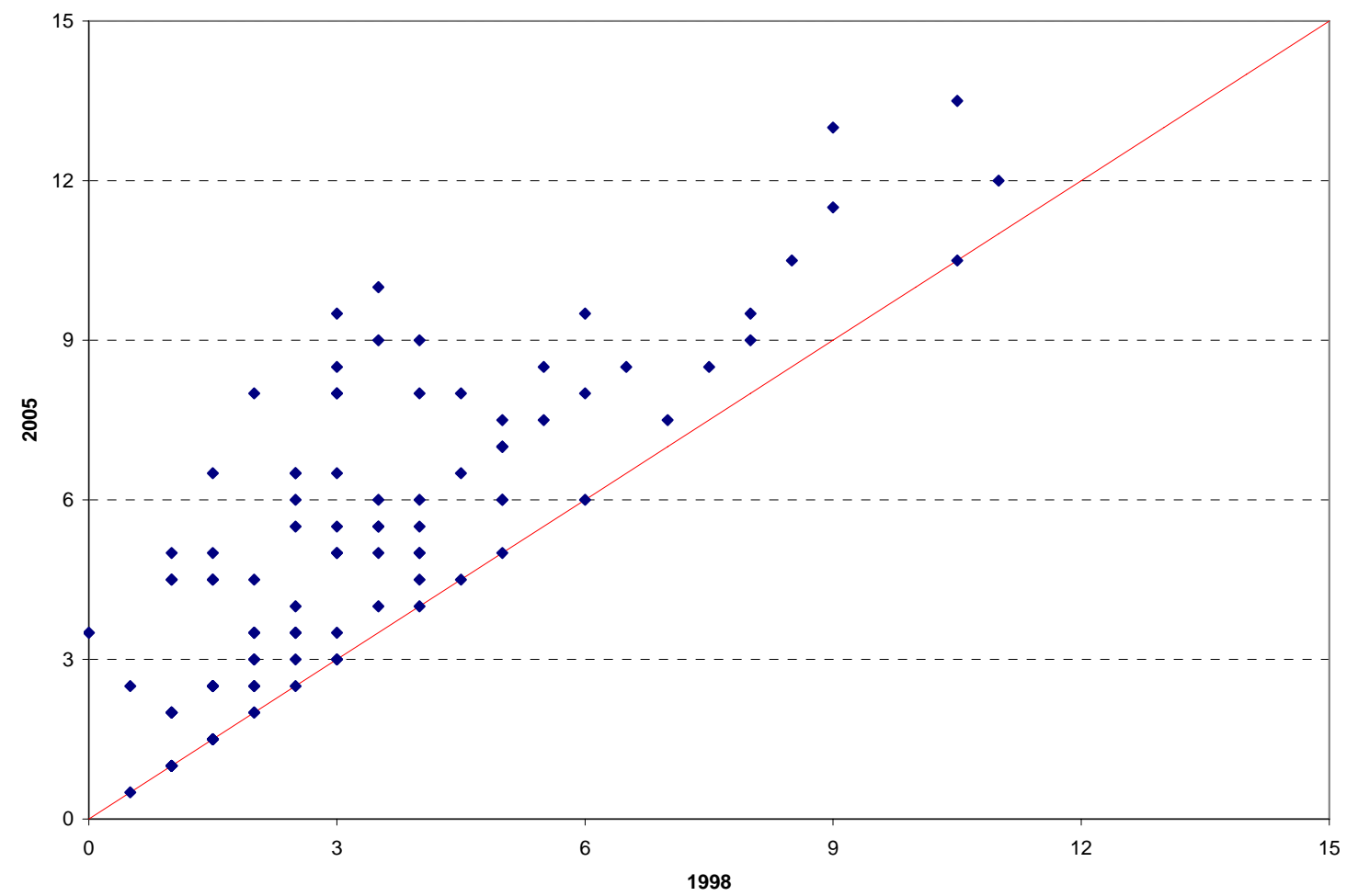


Figure 3. Trends in Transparency by Level of Economic Development: Weighted Averages

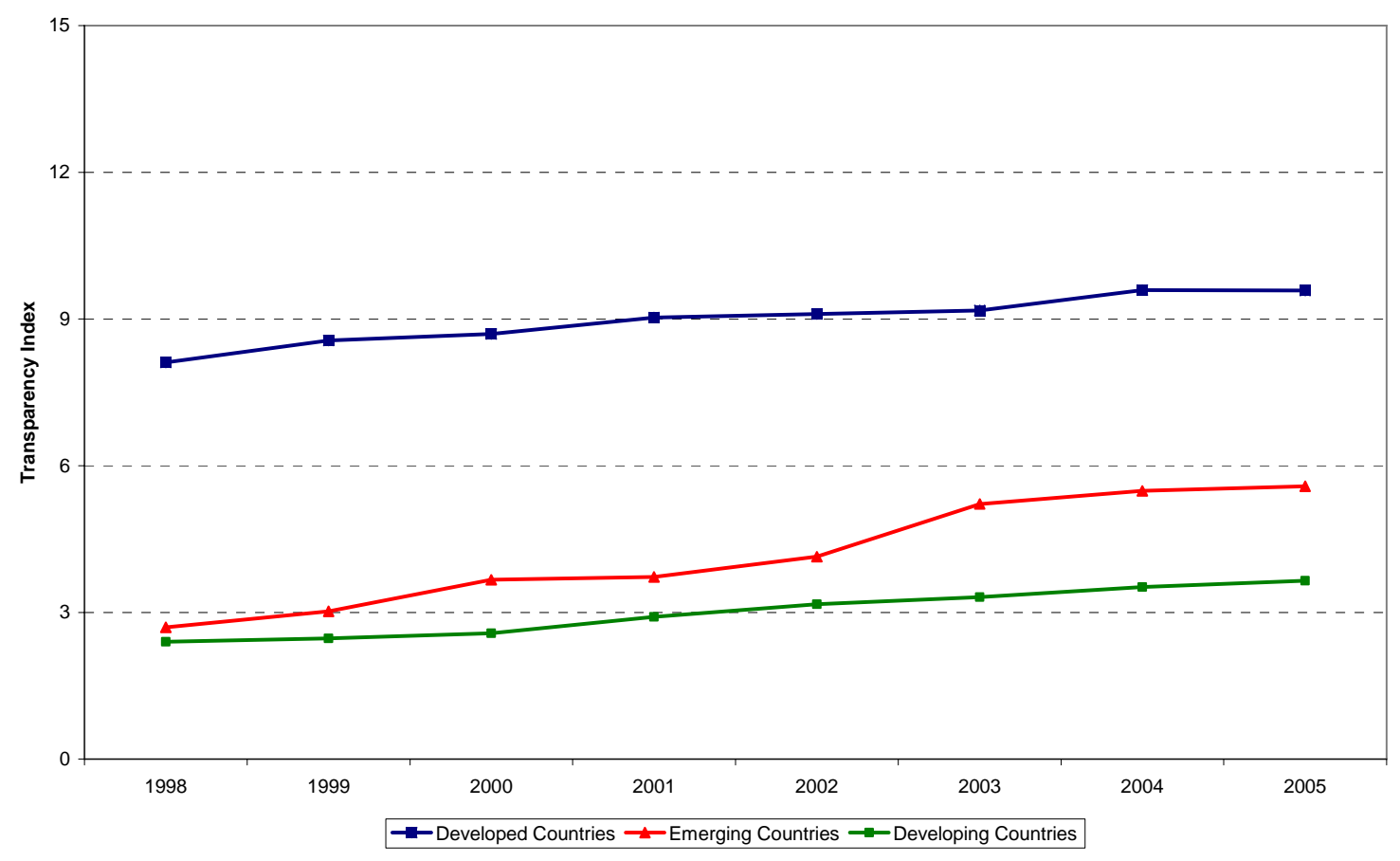


Figure 4. Transparency and Rule of Law

Rule of Law and Central Bank Transparency, Average for 1998-2004

100

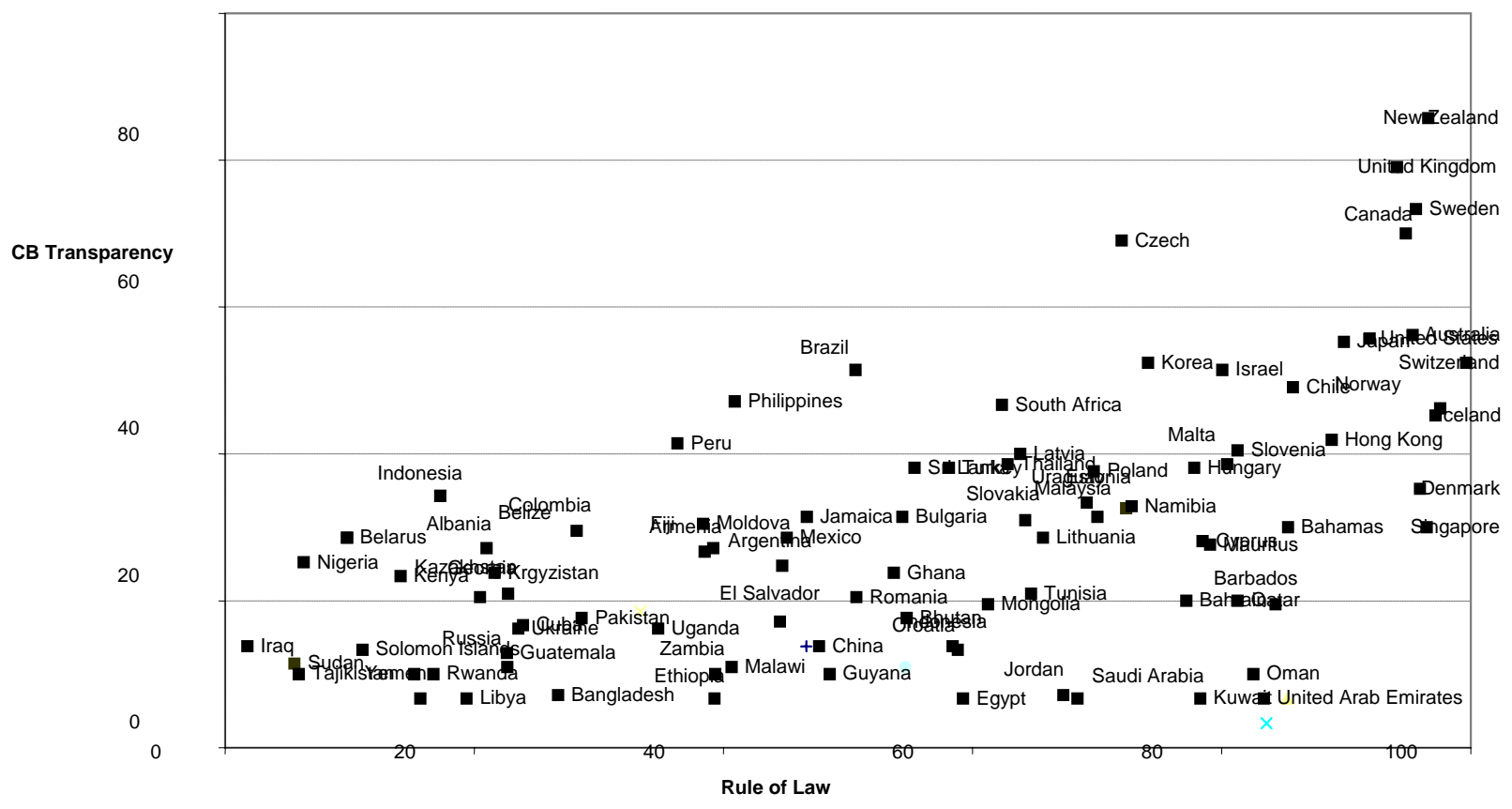


Table 1. Transparency, by Region

\begin{tabular}{llllllll}
1998 & 1999 & 2000 & 2001 & 2002 & 2003 & 2004 & 2005 \\
\hline
\end{tabular}

$\begin{array}{lrrrrrrrr}\text { Africa } & 2.2 & 2.2 & 2.5 & 3.0 & 3.2 & 3.5 & 3.5 & 3.9 \\ \text { Eastern Africa } & 1.7 & 1.8 & 1.9 & 2.4 & 2.6 & 2.6 & 2.6 & 2.8 \\ \text { Ethiopia } & 1 & 1 & 1 & 1 & 1 & 1 & 1 & 1 \\ \text { Kenya } & 2 & 2 & 2.5 & 4.5 & 4.5 & 4.5 & 4.5 & 4.5 \\ \text { Malawi } & 0.5 & 0.5 & 0.5 & 2.5 & 2.5 & 2.5 & 2.5 & 2.5 \\ \text { Mauritius } & 3.5 & 3.5 & 3.5 & 3.5 & 5 & 5 & 5 & 5 \\ \text { Rwanda } & 1.5 & 1.5 & 1.5 & 1.5 & 1.5 & 1.5 & 1.5 & 2.5 \\ \text { Uganda } & 2 & 2.5 & 2.5 & 2.5 & 2.5 & 2.5 & 2.5 & 2.5 \\ \text { Zambia } & 1.5 & 1.5 & 1.5 & 1.5 & 1.5 & 1.5 & 1.5 & 1.5 \\ & & & & & & & & \\ \text { Northern Africa } & 1.4 & 1.4 & 1.6 & 1.6 & 2.0 & 2.0 & 2.0 & 2.3 \\ \text { Egypt } & 1 & 1 & 1 & 1 & 1 & 1 & 1 & 2 \\ \text { Libyan Arab Jamahiriya } & 1 & 1 & 1 & 1 & 1 & 1 & 1 & 1 \\ \text { Sudan } & 1 & 1 & 2 & 2 & 2 & 2 & 2 & 2 \\ \text { Tunisia } & 2.5 & 2.5 & 2.5 & 2.5 & 4 & 4 & 4 & 4 \\ & & & & & & & & \\ \text { Southern Africa } & 3.0 & 3.0 & 3.7 & 5.0 & 5.3 & 5.7 & 6.0 & 7.2 \\ \text { Lesotho } & 1 & 1 & 1.5 & 1.5 & 1.5 & 2.5 & 2.5 & 4.5 \\ \text { Namibia } & 4 & 4 & 4.5 & 4.5 & 5.5 & 5.5 & 6.5 & 8 \\ \text { South Africa } & 4 & 4 & 5 & 9 & 9 & 9 & 9 & 9 \\ \text { Western Africa } & & & & & & & & \\ \text { Ghana } & 2.7 & 2.7 & 2.7 & 2.8 & 2.8 & 3.5 & 3.5 & 3.5 \\ \text { Nigeria } & 3 & 3 & 3 & 3 & 3 & 5 & 5 & 5 \\ \text { Sierra Leone } & 3.5 & 3.5 & 3.5 & 4 & 4 & 4 & 4 & 4 \\ & 1.5 & 1.5 & 1.5 & 1.5 & 1.5 & 1.5 & 1.5 & 1.5\end{array}$


(con't.) Table 1. Transparency, by Region

\begin{tabular}{|c|c|c|c|c|c|c|c|c|}
\hline & 1998 & 1999 & 2000 & 2001 & 2002 & 2003 & 2004 & 2005 \\
\hline \multicolumn{9}{|l|}{ Americas } \\
\hline Latin America and Caribbean & 2.7 & 2.8 & 2.9 & 3.4 & 3.7 & 3.8 & 4.0 & 4.0 \\
\hline East Caribbean & 2.5 & 2.5 & 3 & 5.5 & 5.5 & 5.5 & 5.5 & 5.5 \\
\hline Aruba & 0.5 & 0.5 & 0.5 & 0.5 & 0.5 & 0.5 & 0.5 & 0.5 \\
\hline Bahamas & 4.5 & 4.5 & 4.5 & 4.5 & 4.5 & 4.5 & 4.5 & 4.5 \\
\hline Barbados & 2.5 & 3 & 3 & 3 & 3 & 3 & 3 & 3 \\
\hline Cuba & 2.5 & 2.5 & 2.5 & 2.5 & 2.5 & 2.5 & 2.5 & 2.5 \\
\hline Jamaica & 3 & 3 & 3 & 4.5 & 6.5 & 6.5 & 6.5 & 6.5 \\
\hline Trinidad and Tobago & 3.5 & 3.5 & 3.5 & 3.5 & 3.5 & 4 & 5.5 & 5.5 \\
\hline Central America & 2.4 & 2.4 & 2.4 & 3.0 & 3.0 & 3.1 & 4.1 & 4.1 \\
\hline Belize & 2 & 2 & 2 & 3.5 & 3.5 & 3.5 & 3.5 & 3.5 \\
\hline El Salvador & 2 & 2 & 2 & 3 & 3 & 3 & 3 & 3 \\
\hline Guatemala & 1.5 & 1.5 & 1.5 & 1.5 & 1.5 & 1.5 & 4.5 & 4.5 \\
\hline Mexico & 4 & 4 & 4 & 4 & 4 & 4.5 & 5.5 & 5.5 \\
\hline South America & 3.9 & 4.3 & 4.9 & 5.1 & 5.7 & 6.1 & 6.1 & 6.1 \\
\hline Argentina & 3 & 3 & 3 & 3 & 3 & 5.5 & 5.5 & 5.5 \\
\hline Brazil & 3.5 & 5.5 & 9 & 9 & 9 & 9 & 9 & 9 \\
\hline Chile & 7 & 7 & 7.5 & 7.5 & 7.5 & 7.5 & 7.5 & 7.5 \\
\hline Colombia & 2.5 & 3.5 & 3.5 & 3.5 & 6 & 6 & 6 & 6 \\
\hline Guyana & 1.5 & 1.5 & 1.5 & 1.5 & 1.5 & 1.5 & 1.5 & 1.5 \\
\hline Peru & 4.5 & 4.5 & 4.5 & 6 & 8 & 8 & 8 & 8 \\
\hline \multirow[t]{2}{*}{ Uruguay } & 5 & 5 & 5 & 5 & 5 & 5 & 5 & 5 \\
\hline & 9 & 9.5 & 9.5 & 9.5 & 9.5 & 9.5 & 9.5 & 9.5 \\
\hline North America & 6.3 & 6.7 & 6.7 & 6.7 & 6.7 & 6.7 & 6.7 & 6.7 \\
\hline Bermuda & 1 & 1 & 1 & 1 & 1 & 1 & 1 & 1 \\
\hline Canada & 10.5 & 10.5 & 10.5 & 10.5 & 10.5 & 10.5 & 10.5 & 10.5 \\
\hline United States of America & 7.5 & 8.5 & 8.5 & 8.5 & 8.5 & 8.5 & 8.5 & 8.5 \\
\hline
\end{tabular}


(con't.) Table 1. Transparency, by Region

\begin{tabular}{|c|c|c|c|c|c|c|c|c|}
\hline & 1998 & 1999 & 2000 & 2001 & 2002 & 2003 & 2004 & 2005 \\
\hline \multicolumn{9}{|l|}{ Oceania } \\
\hline & 5.4 & 6.4 & 6.4 & 6.8 & 7.3 & 7.3 & 7.4 & 7.4 \\
\hline Australia and New Zealand & 9.3 & 10.5 & 10.5 & 10.5 & 11.3 & 11.3 & 11.3 & 11.3 \\
\hline Australia & 8 & 8 & 8 & 8 & 9 & 9 & 9 & 9 \\
\hline New Zealand & 10.5 & 13 & 13 & 13 & 13.5 & 13.5 & 13.5 & 13.5 \\
\hline Melanesia & 1.5 & 2.3 & 2.3 & 3.1 & 3.3 & 3.3 & 3.5 & 3.5 \\
\hline Fiji & 1.5 & 4.5 & 4.5 & 4.5 & 4.5 & 4.5 & 4.5 & 4.5 \\
\hline Papua New Guinea & 1 & 1 & 1 & 3.5 & 4 & 4 & 5 & 5 \\
\hline Solomon Islands & 2 & 2 & 2 & 2 & 2 & 2 & 2 & 2 \\
\hline Vanuatu & 1.5 & 1.5 & 1.5 & 2.5 & 2.5 & 2.5 & 2.5 & 2.5 \\
\hline Asia & 3.0 & 3.2 & 3.5 & 3.8 & 4.3 & 4.6 & 4.9 & 5.1 \\
\hline Central Asia & 2.7 & 2.7 & 2.7 & 3.0 & 3.0 & 2.7 & 3.3 & 4.0 \\
\hline Kazakhstan & 3.5 & 3.5 & 3.5 & 3.5 & 3.5 & 3.5 & 3.5 & 5.5 \\
\hline Kyrgyzstan & 3 & 3 & 3 & 4 & 4 & 3 & 5 & 5 \\
\hline Tajikistan & 1.5 & 1.5 & 1.5 & 1.5 & 1.5 & 1.5 & 1.5 & 1.5 \\
\hline Eastern Asia & 4.6 & 4.8 & 5.2 & 5.2 & 5.7 & 6.3 & 6.6 & 6.6 \\
\hline China & 1 & 1 & 1 & 1 & 1.5 & 4.5 & 4.5 & 4.5 \\
\hline Hong Kong & 5 & 6 & 6 & 6 & 7 & 7 & 7 & 7 \\
\hline Korea & 6.5 & 6.5 & 8 & 8.5 & 8.5 & 8.5 & 8.5 & 8.5 \\
\hline Japan & 8 & 8 & 8.5 & 8 & 8 & 8 & 9.5 & 9.5 \\
\hline Mongolia & 2.5 & 2.5 & 2.5 & 2.5 & 3.5 & 3.5 & 3.5 & 3.5 \\
\hline Southern Asia & 2.3 & 2.3 & 2.3 & 2.4 & 3.0 & 3.5 & 3.9 & 3.9 \\
\hline Bangladesh & 0 & 0 & 0 & 0.5 & 0.5 & 3 & 3.5 & 3.5 \\
\hline Bhutan & 2 & 2 & 2 & 2 & 3.5 & 3.5 & 3.5 & 3.5 \\
\hline India & 2 & 2 & 2 & 2 & 2 & 2 & 2 & 2 \\
\hline Pakistan & 2.5 & 2.5 & 2.5 & 2.5 & 2.5 & 2.5 & 3.5 & 3.5 \\
\hline \multirow[t]{2}{*}{ Sri Lanka } & 5 & 5 & 5 & 5 & 6.5 & 6.5 & 7 & 7 \\
\hline & & & & 39 & & & & \\
\hline
\end{tabular}


(con't.) Table 1. Transparency, by Region

\begin{tabular}{|c|c|c|c|c|c|c|c|c|}
\hline & 1998 & 1999 & 2000 & 2001 & 2002 & 2003 & 2004 & 2005 \\
\hline South-East Asia & 3.0 & 3.9 & 4.9 & 5.5 & 6.4 & 7.1 & 7.3 & 7.5 \\
\hline Indonesia & 3 & 4.5 & 4.5 & 4.5 & 4.5 & 7 & 8 & 8 \\
\hline Malaysia & 4 & 4 & 5 & 5 & 5 & 5 & 5 & 5 \\
\hline Philippines & 3.5 & 5 & 5 & 6 & 10 & 10 & 10 & 10 \\
\hline Singapore & 2.5 & 4 & 4 & 5.5 & 4.5 & 5.5 & 5.5 & 6.5 \\
\hline Thailand & 2 & 2 & 6 & 6.5 & 8 & 8 & 8 & 8 \\
\hline Western Asia & 2.3 & 2.4 & 2.5 & 2.8 & 3.2 & 3.2 & 3.3 & 3.4 \\
\hline Armenia & 4 & 4 & 4 & 4 & 4 & 4 & 4 & 4 \\
\hline Bahrain & 3 & 3 & 3 & 3 & 3 & 3 & 3 & 3 \\
\hline Cyprus & 2.5 & 2.5 & 2.5 & 3.5 & 6 & 6 & 6.5 & 6.5 \\
\hline Georgia & 3 & 3 & 3 & 3 & 3 & 3.5 & 3.5 & 3.5 \\
\hline Iraq & 2 & 2 & 2 & 2 & 2 & 2 & 2.5 & 2.5 \\
\hline Israel & 5.5 & 7 & 7.5 & 8.5 & 8.5 & 8.5 & 8.5 & 8.5 \\
\hline Jordan & 1 & 1 & 1 & 1 & 1 & 1 & 1.5 & 2 \\
\hline Kuwait & 1 & 1 & 1 & 1 & 1 & 1 & 1 & 1 \\
\hline Oman & 1.5 & 1.5 & 1.5 & 1.5 & 1.5 & 1.5 & 1.5 & 1.5 \\
\hline Qatar & 3 & 3 & 3 & 3 & 3 & 3 & 3 & 3 \\
\hline Saudi Arabia & 1 & 1 & 1 & 1 & 1 & 1 & 1 & 1 \\
\hline Turkey & 3 & 2 & 4 & 5.5 & 8.5 & 8.5 & 8.5 & 8.5 \\
\hline United Arab Emirates & 1 & 1 & 1 & 1 & 1 & 1 & 1 & 2 \\
\hline Yemen & 1 & 1 & 1 & 1 & 1 & 1 & 1 & 1 \\
\hline
\end{tabular}


(con't.) Table 1. Transparency, by Region

\begin{tabular}{|c|c|c|c|c|c|c|c|c|}
\hline & 1998 & 1999 & 2000 & 2001 & 2002 & 2003 & 2004 & 2005 \\
\hline Europe & 5.2 & 5.5 & 5.8 & 6.2 & 6.7 & 7.1 & 7.4 & 7.5 \\
\hline Eastern Europe & 3.4 & 3.9 & 4.3 & 4.5 & 5.4 & 5.5 & 6.0 & 6.4 \\
\hline Belarus & 1.5 & 3.5 & 5 & 5 & 5 & 5 & 5 & 5 \\
\hline Bulgaria & 4.5 & 4.5 & 4.5 & 4.5 & 4.5 & 4.5 & 6 & 6.5 \\
\hline Czech Republic & 9 & 10 & 10 & 10 & 10.5 & 11.5 & 11.5 & 11.5 \\
\hline Hungary & 3 & 3 & 4.5 & 5.5 & 8 & 8 & 8 & 9.5 \\
\hline Poland & 3 & 5 & 5 & 6.5 & 6.5 & 6.5 & 7 & 8 \\
\hline Republic of Moldova & 4 & 4 & 4 & 5 & 5 & 5 & 5 & 5 \\
\hline Romania & 1.5 & 1.5 & 1.5 & 1.5 & 4.5 & 4.5 & 6.5 & 6.5 \\
\hline Russian Federation & 1.5 & 1.5 & 1.5 & 1.5 & 1.5 & 1.5 & 2.5 & 2.5 \\
\hline Slovakia & 4 & 4 & 4.5 & 3.5 & 5.5 & 5.5 & 5.5 & 6 \\
\hline Ukraine & 2 & 2 & 2 & 2 & 3 & 3 & 3 & 3 \\
\hline Northern Europe & 6.4 & 6.6 & 6.9 & 7.2 & 7.6 & 7.8 & 7.8 & 7.9 \\
\hline Denmark & 5 & 5 & 5 & 5 & 5 & 6 & 6 & 6 \\
\hline Estonia & 5 & 5 & 5.5 & 5.5 & 5.5 & 5.5 & 5 & 6 \\
\hline Iceland & 5.5 & 5.5 & 7 & 7 & 7.5 & 7.5 & 7.5 & 7.5 \\
\hline Latvia & 6 & 6 & 6 & 6 & 6 & 6 & 6 & 6 \\
\hline Lithuania & 4 & 4 & 4 & 4.5 & 4.5 & 4.5 & 4.5 & 4.5 \\
\hline Norway & 6 & 6 & 6 & 7.5 & 7.5 & 7.5 & 8 & 8 \\
\hline Sweden & 9 & 9 & 10 & 10 & 13 & 13 & 13 & 13 \\
\hline United Kingdom & 11 & 12 & 12 & 12 & 12 & 12 & 12 & 12 \\
\hline Southern Europe & 3.8 & 3.8 & 3.9 & 4.1 & 4.8 & 5.5 & 5.8 & 5.8 \\
\hline Albania & 3.5 & 3.5 & 3.5 & 3.5 & 3.5 & 5 & 6 & 6 \\
\hline Croatia & 1.5 & 1.5 & 1.5 & 2.5 & 2.5 & 2.5 & 2.5 & 2.5 \\
\hline Malta & 5 & 5 & 5.5 & 5.5 & 5.5 & 7 & 7 & 7 \\
\hline Slovenia & 5 & 5 & 5 & 5 & 7.5 & 7.5 & 7.5 & 7.5 \\
\hline Western Europe & 7.3 & 7.8 & 8.0 & 9.0 & 9.0 & 9.5 & 10.0 & 10.0 \\
\hline Switzerland & 6 & 7 & 7.5 & 8 & 8 & 9 & 9.5 & 9.5 \\
\hline European Union & 8.5 & 8.5 & 8.5 & 10 & 10 & 10 & 10.5 & 10.5 \\
\hline
\end{tabular}


Table 2. Components of the Index for the 14 countries with extreme values

\begin{tabular}{|c|c|c|c|c|c|c|c|c|c|c|c|c|c|c|c|c|}
\hline & $\mathrm{TI}$ & $1 a$ & $1 b$ & 1c & $2 a$ & $2 b$ & $2 c$ & $3 a$ & $3 b$ & $3 c$ & $4 a$ & $4 b$ & $4 \mathrm{C}$ & $5 a$ & $5 b$ & $5 c$ \\
\hline New Zealand & 13.5 & 1 & 1 & 1 & 1 & 1 & 1 & 1 & 1 & 1 & 1 & 0.5 & 1 & 1 & 0.5 & 0.5 \\
\hline Sweden & 13 & 0.5 & 1 & 0.5 & 1 & 1 & 1 & 1 & 1 & 1 & 1 & 0.5 & 1 & 1 & 1 & 0.5 \\
\hline UK & 12 & 1 & 1 & 1 & 0.5 & 1 & 1 & 1 & 1 & 1 & 1 & 0.5 & 0 & 1 & 0.5 & 0.5 \\
\hline Czech Republic & 11.5 & 1 & 1 & 1 & 1 & 1 & 1 & 1 & 1 & 0.5 & 1 & 0.5 & 0 & 0 & 0.5 & 1 \\
\hline Canada & 10.5 & 1 & 1 & 1 & 1 & 1 & 0.5 & 1 & 0 & 0 & 1 & 1 & 0 & 1 & 0.5 & 0.5 \\
\hline Euro area & 10.5 & 1 & 1 & 1 & 1 & 1 & 1 & 1 & 0 & 0 & 1 & 0.5 & 0 & 1 & 0.5 & 0.5 \\
\hline Philippines & 10 & 1 & 1 & 1 & 1 & 0 & 1 & 1 & 1 & 0.5 & 1 & 0.5 & 0 & 0 & 0.5 & 0.5 \\
\hline Bermuda & 1 & 0.5 & 0 & 0.5 & 0 & 0 & 0 & 0 & 0 & 0 & 0 & 0 & 0 & 0 & 0 & 0 \\
\hline Ethiopia & 1 & 0.5 & 0 & 0.5 & 0 & 0 & 0 & 0 & 0 & 0 & 0 & 0 & 0 & 0 & 0 & 0 \\
\hline Kuwait & 1 & 0.5 & 0 & 0.5 & 0 & 0 & 0 & 0 & 0 & 0 & 0 & 0 & 0 & 0 & 0 & 0 \\
\hline Libya & 1 & 0.5 & 0 & 0.5 & 0 & 0 & 0 & 0 & 0 & 0 & 0 & 0 & 0 & 0 & 0 & 0 \\
\hline Yemen & 1 & 0.5 & 0 & 0.5 & 0 & 0 & 0 & 0 & 0 & 0 & 0 & 0 & 0 & 0 & 0 & 0 \\
\hline Aruba & 0.5 & 0 & 0 & 0.5 & 0 & 0 & 0 & 0 & 0 & 0 & 0 & 0 & 0 & 0 & 0 & 0 \\
\hline Saudi Arabia & 0 & 0 & 0 & 0 & 0 & 0 & 0 & 0 & 0 & 0 & 0 & 0 & 0 & 0 & 0 & 0 \\
\hline
\end{tabular}


Table 3. Regional Transparency Index (Weighted)

\begin{tabular}{|c|c|c|c|c|c|c|c|c|}
\hline & 1998 & 1999 & 2000 & 2001 & 2002 & 2003 & 2004 & 2005 \\
\hline Africa & 2.58 & 2.56 & 2.90 & 4.27 & 4.46 & 5.05 & 5.32 & 5.38 \\
\hline Eastern Africa & 1.83 & 1.91 & 2.08 & 2.85 & 3.06 & 3.10 & 3.03 & 3.00 \\
\hline Northern Africa & 1.21 & 1.20 & 1.25 & 1.27 & 1.55 & 1.62 & 1.67 & 2.10 \\
\hline Southern Africa & 3.98 & 3.98 & 4.97 & 8.84 & 8.86 & 8.87 & 8.90 & 8.95 \\
\hline Western Africa & 3.37 & 3.38 & 3.42 & 3.86 & 3.84 & 4.08 & 4.08 & 4.07 \\
\hline Americas & 7.02 & 8.04 & 8.20 & 8.20 & 8.30 & 8.37 & 8.43 & 8.43 \\
\hline \multicolumn{9}{|l|}{ Latin America and } \\
\hline Caribbean & 2.84 & 2.88 & 3.14 & 4.62 & 4.94 & 5.13 & 5.54 & 5.54 \\
\hline Central America & 3.84 & 3.86 & 3.88 & 3.90 & 3.89 & 4.36 & 5.41 & 5.41 \\
\hline South America & 3.59 & 4.71 & 6.67 & 6.60 & 7.63 & 7.94 & 7.94 & 7.98 \\
\hline North America & 7.70 & 8.63 & 8.64 & 8.63 & 8.63 & 8.65 & 8.65 & 8.66 \\
\hline Oceania & 8.22 & 8.54 & 8.51 & 8.56 & 9.51 & 9.54 & 9.55 & 9.56 \\
\hline \multicolumn{9}{|l|}{ Australia and New } \\
\hline Zealand & 8.32 & 8.62 & 8.59 & 8.62 & 9.57 & 9.59 & 9.60 & 9.61 \\
\hline Melanesia & 1.21 & 2.19 & 2.10 & 3.69 & 4.02 & 4.04 & 4.61 & 4.62 \\
\hline Asia & 5.60 & 5.75 & 6.20 & 5.81 & 5.90 & 6.48 & 7.16 & 7.08 \\
\hline Central Asia & 3.36 & 3.35 & 3.37 & 3.44 & 3.44 & 3.38 & 3.48 & 5.33 \\
\hline Eastern Asia & 6.51 & 6.60 & 7.04 & 6.47 & 6.48 & 7.16 & 8.05 & 7.89 \\
\hline Southern Asia & 1.98 & 1.98 & 1.99 & 2.02 & 2.06 & 2.23 & 2.38 & 2.38 \\
\hline South-East Asia & 2.89 & 3.80 & 4.91 & 5.40 & 6.05 & 7.06 & 7.39 & 7.54 \\
\hline Western Asia & 2.59 & 2.46 & 3.04 & 3.52 & 4.34 & 4.47 & 4.56 & 5.03 \\
\hline Europe & 8.27 & 8.57 & 8.58 & 9.60 & 9.70 & 9.74 & 10.10 & 10.02 \\
\hline Eastern Europe & 2.82 & 3.71 & 3.62 & 3.98 & 4.50 & 4.53 & 5.05 & 5.22 \\
\hline Northern Europe & 9.78 & 10.49 & 10.62 & 10.74 & 11.07 & 11.12 & 11.18 & 11.13 \\
\hline Southern Europe & 3.37 & 3.46 & 3.50 & 3.87 & 4.89 & 5.12 & 5.17 & 5.13 \\
\hline Western Europe & 8.40 & 8.44 & 8.46 & 9.92 & 9.92 & 9.96 & 10.46 & 10.46 \\
\hline
\end{tabular}


Table 4. Determinants of Transparency, 1998-2004 Averages $\dagger$

\begin{tabular}{|c|c|c|c|c|}
\hline & $\mathrm{I}$ & II & III & IV \\
\hline \multirow[t]{2}{*}{ Constant } & $-8.69 *$ & $-9.49 *$ & $-7.29 *$ & $-7.01 *$ \\
\hline & $(-3.31)$ & $(-3.85)$ & $(-3.12)$ & $(-2.46)$ \\
\hline \multirow[t]{2}{*}{ Past inflation } & -1.17 & -1.90 & -0.50 & 0.02 \\
\hline & $(-0.53)$ & $(-0.88)$ & $(-0.24)$ & $(0.01)$ \\
\hline \multirow[t]{2}{*}{ Exchange Rate Regime } & $0.29 *$ & $0.30 *$ & $0.24 *$ & $0.28 *$ \\
\hline & $(4.66)$ & $(4.77)$ & $(4.09)$ & $(4.52)$ \\
\hline \multirow[t]{2}{*}{ Financial Depth } & -0.00 & -0.00 & 0.00 & -0.01 \\
\hline & $(-0.63)$ & $(-0.37)$ & $(0.30)$ & $(-0.85)$ \\
\hline \multirow{2}{*}{ GDP per Capita } & $1.10^{*}$ & $1.25 *$ & $0.86^{*}$ & 0.80 \\
\hline & $(3.07)$ & $(3.88)$ & $(2.81)$ & $(1.90)$ \\
\hline \multirow[t]{2}{*}{ Rule of Law } & 0.03 & & & \\
\hline & $(1.66)$ & & & \\
\hline Political Stability & & $\begin{array}{c}0.02 \\
(1.43)\end{array}$ & & \\
\hline Voice and Accountability & & & $\begin{array}{l}0.04^{*} \\
(3.41)\end{array}$ & \\
\hline Government Efficiency & & & & $\begin{array}{c}0.04 * \\
(2.18)\end{array}$ \\
\hline R-Squared & 0.55 & 0.54 & 0.60 & 0.56 \\
\hline
\end{tabular}

$*$ denotes significance at $5 \%$

$\dagger$ t-statistics in parentheses 
Table 5. Further Determinants of Transparency, 1998-2004 Averages

\begin{tabular}{lcccc}
\hline \multirow{3}{*}{ Constant } & I & II & III & IV \\
& $-7.02^{*}$ & $-8.04^{*}$ & $-5.51^{*}$ & -4.87 \\
Past inflation & $(2.46)$ & $(2.83)$ & $(-2.13)$ & $(-1.60)$ \\
& -0.65 & -1.27 & 0.35 & 0.83 \\
Openness & $(-0.27)$ & $(-0.52)$ & $(0.15)$ & $(0.33)$ \\
& $-0.01^{*}$ & $-0.01^{*}$ & $-0.01^{*}$ & $-0.01^{*}$ \\
Openness*ER Regime & $(-2.17)$ & $(-2.28)$ & $(-2.12)$ & $(-2.13)$ \\
& $0.01^{*}$ & $0.01^{*}$ & $0.01^{*}$ & $0.01^{*}$ \\
Financial Depth & $(3.18)$ & $(3.06)$ & $(2.30)$ & $(3.14)$ \\
& -0.01 & 0.01 & 0.01 & -0.01 \\
GDP per Capita & $(-0.38)$ & $(0.01)$ & $(0.57)$ & $(-0.62)$ \\
& $1.14^{*}$ & $1.35^{*}$ & $0.87^{*}$ & 0.73 \\
Rule of Law & $(2.93)$ & $(3.74)$ & $(2.53)$ & $(1.62)$ \\
Political Stability & 0.03 & & & \\
Voice and Accountability & $(1.70)$ & & & \\
Government Efficiency & & 0.02 & & \\
& & $(1.13)$ & & $0.04^{*}$ \\
R-Squared & & & $(3.28)$ & \\
\hline
\end{tabular}

* denotes significance at $5 \%$

$\dagger t$-statistics in parentheses 
Table 6. Determinants of Transparency, Fixed Effects Models

\begin{tabular}{lcccc}
\hline \multirow{2}{*}{ Constant } & I & II & III & IV \\
& -34.52 & -40.65 & -41.50 & -40.87 \\
Past inflation & $(-0.09)$ & $(-0.11)$ & $(-0.11)$ & $(-0.11)$ \\
& -0.03 & 0.10 & 0.10 & -0.04 \\
ER Regime Dummy & $(-0.09)$ & $(0.25)$ & $(0.27)$ & $(-0.11)$ \\
Financial Depth & $0.09^{*}$ & $0.12^{*}$ & $0.12^{*}$ & $0.11^{*}$ \\
& $(2.52)$ & $(3.41)$ & $(3.39)$ & $(3.19)$ \\
GDP per Capita & -0.00 & -0.00 & -0.00 & -0.00 \\
Rule of Law & $(-0.16)$ & $(-0.10)$ & $(-0.13)$ & $(-0.19)$ \\
Political Stability & $4.61^{*}$ & $5.05^{*}$ & $5.11^{*}$ & $5.15^{*}$ \\
Voice and Accountability & $(9.35)$ & $(10.41)$ & $(10.70)$ & $(10.79)$ \\
Government Efficiency & $-0.04^{*}$ & & & \\
& $(-3.22)$ & & & \\
Haussman test & & $(-0.47)$ & & \\
R-Squared & & & & \\
\end{tabular}

* denotes significance at $5 \%$

$\dagger \mathrm{t}$-statistics in parentheses 
Table 7. Determinants of Transparency, Fixed Effects Models

\begin{tabular}{|c|c|c|c|c|}
\hline & $\mathrm{I}$ & II & III & IV \\
\hline \multirow[t]{2}{*}{ Constant } & -31.95 & -38.33 & -39.40 & -38.37 \\
\hline & $(-0.08)$ & $(-0.10)$ & $(-0.10)$ & $(-0.10)$ \\
\hline \multirow[t]{2}{*}{ Past inflation } & -0.09 & 0.07 & 0.09 & -0.12 \\
\hline & $(-0.24)$ & $(0.19)$ & $(0.22)$ & $(-0.29)$ \\
\hline \multirow[t]{2}{*}{ Openness } & -0.01 & -0.01 & -0.01 & -0.01 \\
\hline & $(-0.70)$ & $(-0.43)$ & $(-0.40)$ & $(-0.37)$ \\
\hline \multirow[t]{2}{*}{ Openness*ER Dummy } & 0.01 & $0.01 *$ & $0.01 *$ & $0.01 *$ \\
\hline & $(1.97)$ & $(2.33)$ & $(2.26)$ & $(2.29)$ \\
\hline \multirow[t]{2}{*}{ Financial Depth } & -0.01 & -0.01 & -0.01 & -0.01 \\
\hline & $(-0.55)$ & $(-0.54)$ & $(-0.61)$ & $(-0.69)$ \\
\hline \multirow[t]{2}{*}{ GDP per Capita } & $4.46 *$ & $4.89 *$ & $4.94 *$ & $4.99 *$ \\
\hline & $(8.71)$ & (9.54) & $(9.76)$ & $(9.87)$ \\
\hline \multirow[t]{2}{*}{ Rule of Law } & $-0.04^{*}$ & & & \\
\hline & $(-3.68)$ & & & \\
\hline \multirow[t]{2}{*}{ Political Stability } & & -0.00 & & \\
\hline & & $(-0.31)$ & & \\
\hline \multirow[t]{2}{*}{ Voice and Accountability } & & & 0.01 & \\
\hline & & & $(0.83)$ & \\
\hline \multirow[t]{2}{*}{ Government Efficiency } & & & & $-0.02 *$ \\
\hline & & & & $(-1.72)$ \\
\hline Haussman test & $13.36^{*}$ & $19.10^{*}$ & $21.92 *$ & $19.47^{*}$ \\
\hline R-Squared & 0.97 & 0.97 & 0.97 & 0.97 \\
\hline
\end{tabular}


Table 8. Effect of Transparency on Inflation Variability (instrumental variables pooled regressions)

\begin{tabular}{lcccccc}
\hline \multirow{3}{*}{ Constant } & I & II & III & IV & V & VI \\
& $7.59^{*}$ & $7.41^{*}$ & $7.43^{*}$ & 1.45 & $6.94^{*}$ & 1.66 \\
Transparency Index & $(7.44)$ & $(7.93)$ & $(7.21)$ & $(1.36)$ & $(7.73)$ & $(1.64)$ \\
& $-1.23^{*}$ & $-1.27^{*}$ & $-1.00^{*}$ & -0.30 & $-1.04^{*}$ & $-0.49^{*}$ \\
Openness & $(-5.79)$ & $(-5.54)$ & $(-4.69)$ & $(-1.66)$ & $(-4.67)$ & $(-2.69)$ \\
& & 0.01 & & & $0.01^{*}$ & 0.00 \\
Financial Depth & & $(1.51)$ & & & $(2.24)$ & $(0.21)$ \\
& & & $-0.01^{*}$ & & $-0.02^{*}$ & $0.01^{*}$ \\
Past Inflation & & & $(-2.60)$ & & $(-3.18)$ & $(2.12)$ \\
& & & & $29.36^{*}$ & & $29.67^{*}$ \\
Number of observations & 579 & 546 & 562 & 578 & 524 & 531 \\
& & & & & & \\
Sum of Sq. Res. & 19561 & 19452 & 19452 & 8216 & 19242 & 8131 \\
\hline
\end{tabular}

* denotes significance at $5 \%$

$\dagger t$-statistics in parantheses

Note: Dependent variable is inflation variability, which is the standard deviation of the inflation rate for 12 months. Transparency is the fitted value of transparency from the first stage regression on constant and rule of law. 
Table 9. Effect of Transparency on Inflation Persistence (instrumental variables pooled regressions)

\begin{tabular}{lcccccc}
\hline & $\mathrm{I}$ & $\mathrm{II}$ & $\mathrm{III}$ & $\mathrm{IV}$ & $\mathrm{V}$ & $\mathrm{VI}$ \\
Constant & $0.79^{*}$ & $0.82^{*}$ & $0.79^{*}$ & $0.77^{*}$ & $0.80^{*}$ & $0.79 *$ \\
& $(18.90)$ & $(18.80)$ & $(18.27)$ & $(14.91)$ & $(17.72)$ & $(15.74)$ \\
Transparency Index & $-0.02^{*}$ & -0.02 & -0.01 & -0.02 & -0.01 & -0.01 \\
& $(-2.05)$ & $(-1.90)$ & $(-0.45)$ & $(-1.57)$ & $(-0.91)$ & $(-0.81)$ \\
Openness & & -0.01 & & & 0.01 & 0.01 \\
& & $(-0.79)$ & & & $(0.28)$ & $(0.18)$ \\
Financial Depth & & & $-0.01^{*}$ & & -0.01 & -0.01 \\
& & & $(-2.26)$ & & $(-1.93)$ & $(-1.73)$ \\
Past Inflation & & & & 0.10 & & 0.06 \\
& & & & $(0.65)$ & & $(0.40)$ \\
Number of observations & 568 & 538 & 552 & 567 & 524 & 523 \\
Sum of Sq. Res. & 49 & 44 & 46 & 49 & 42 & 42 \\
\hline
\end{tabular}

* denotes significance at $5 \%$

$\dagger$ t-statistics in parentheses.

Note: Dependent variable is inflation persistence, which is the estimated coefficient of the regression where monthly inflation data is used and inflation is regressed on the inflation in the previous month.

Transparency is the fitted value of transparency from the first

stage regression on a constant and rule of law. 
Table 10. Alternative Specification for Inflation Persistence instrumental variables pooled regressions

\begin{tabular}{lccc}
\hline & I & II & III \\
Constant & $0.01^{*}$ & $0.02^{*}$ & $0.02^{*}$ \\
& $(3.77)$ & $(3.19)$ & $(3.71)$ \\
Lag_inf & $1.00^{*}$ & $1.00^{*}$ & $0.92^{*}$ \\
& $(4.28)$ & $(4.26)$ & $(4.05)$ \\
Lag_inf* transparency & -0.16 & -0.16 & -0.15 \\
& $(-1.92)$ & $(-1.93)$ & $(-1.85)$ \\
Openness & & -0.00 & $0.00^{*}$ \\
Financial Depth & & $(-0.45)$ & $(2.45)$ \\
& & & $-0.00 *$ \\
DW test & & & $(-4.96)$ \\
R-Squared & 1.42 & 1.42 & 1.40 \\
\hline
\end{tabular}

* denotes significance at 5\%

†t-statistics in parentheses

Transparency is instrumented as described in the text.

Note: (1) Dependent variable is inflation

(2) Transparency is the fitted value of transparency from the first stage regression on a constant and rule of law. 
Table 11. Effects of Transparency on Output Variability

(instrumental variables pooled regressions)

\begin{tabular}{lcccccc}
\hline & $\mathrm{I}$ & $\mathrm{II}$ & $\mathrm{III}$ & $\mathrm{IV}$ & $\mathrm{V}$ & $\mathrm{VI}$ \\
Constant & $3.81^{*}$ & $3.63^{*}$ & $3.76^{*}$ & $3.38^{*}$ & $3.52^{*}$ & $3.18^{*}$ \\
& $(10.81)$ & $(9.00)$ & $(10.48)$ & $(9.00)$ & $(8.38)$ & $(7.35)$ \\
Transparency Index & $-0.33^{*}$ & $-0.41^{*}$ & $-0.38^{*}$ & $-0.27^{*}$ & $-0.39^{*}$ & $-0.36^{*}$ \\
& $(-4.51)$ & $(-5.66)$ & $(-4.46)$ & $(-3.50)$ & $(-4.49)$ & $(-4.06)$ \\
Openness & & 0.01 & & & $0.01^{*}$ & $0.00^{*}$ \\
& & $(2.98)$ & & & $(2.52)$ & $(2.21)$ \\
Financial Depth & & & $0.01^{*}$ & & 0.01 & 0.01 \\
& & & $(1.87)$ & & $(0.51)$ & $(1.11)$ \\
Past Inflation & & & & $2.24^{*}$ & & $2.36^{*}$ \\
& & & & $(3.48)$ & & $(3.29)$ \\
Number of obs. & 648 & 606 & 626 & 618 & 586 & 566 \\
Sum of Sq. Res. & 3181 & 2987 & 3064 & 2946 & 2906 & 2748 \\
\hline
\end{tabular}

* denotes significance at $5 \%$

$\dagger t$-statistics in parentheses

Note: (1) Dependent variable is output variability

(2) Output variability is computed as the standard deviation of the annual GDP growth rate over the period $t-2$ to $t$ (where $t$ denotes the current year)

(3) Transparency is the fitted value of transparency from the first stage regression on a constant and rule of law. 